\section{Risk of multisystem disease in isolated ocular angioma (haemangioblastoma)}

EDITOR-Ocular angioma (haemangioblastoma) is the most common presenting feature of the multisystem familial cancer syndrome von Hippel-Lindau disease (VHL). ${ }^{1}$ Recognition of VHL is important because of the opportunity to reduce morbidity and mortality by early diagnosis of renal cell carcinoma, phaeochromocytoma, and cerebellar, spinal, and ocular haemangioblastomas. Although the finding of typical and multiple ocular lesions indicates VHL, the risk of multisystem disease in those presenting with a single ocular lesion has not been determined. That such risk exists is shown by the presence of patients with solitary angiomas in families with VHL, and the identification of mutations in the VHL gene in affected subjects without a family history of disease owing to non-penetrance for VHL manifestations in relatives and a significant new mutation rate. Consequently, the management of patients with a solitary ocular lesion may be inappropriate, such that patients with VHL may be falsely reassured, and others without symptoms may be subjected to unnecessary surveillance. On the basis of previous estimates, we have used a Baysian approach to calculate approximate risks for VHL disease in a patient presenting with a single ocular angioma in the context of other clinical and molecular information available.

The proportion of VHL patients who have a solitary ocular angioma after ophthalmic examination has been calculated in previous work on a cohort of VHL gene carriers, ${ }^{2}$ and this proportion, like all the following proportions, can be used as an estimate of a corresponding conditional probability. However, calculation of the reverse conditional probability, that is, the probability of VHL given a diagnosis of solitary ocular angioma, requires the use of Bayes' theorem, as shown below:

$$
\operatorname{Pr}(V H L \mid s)=\frac{\operatorname{Pr}(s \mid V H L) \times \operatorname{Pr}(V H L)}{\operatorname{Pr}(s \mid V H L) \times \operatorname{Pr}(V H L)+\operatorname{Pr}(s \mid \overline{V H L}) \times \operatorname{Pr}(\overline{V H L})}
$$

Here $\operatorname{Pr}(V H L \mid s)$ represents the probability of VHL disease in a patient presenting with a single ocular angioma. $\operatorname{Pr}(s \mid V H L)$ represents the probability of a solitary angioma given a diagnosis of VHL disease, which has been estimated in a recent survey of VHL gene carriers ${ }^{2}$ as 0.20 . $\operatorname{Pr}(V H L)$ represents the population prevalence of VHL disease, which is taken as $18.9 \times 10^{-6} .^{3} \operatorname{Pr}(s \mid \overline{V H L})$ represents the prevalence of patients who harbour a solitary ocular lesion, but who do not have underlying VHL disease. The existence of non-VHL ocular angioma has been confirmed recently in a British population using a

Table 1 Estimates from previous work ${ }^{1-4}{ }^{6}$ of the conditional probabilities of four clinical and molecular states given the presence of VHL disease for four age groups (see text)

\begin{tabular}{llllll}
\hline & & \multicolumn{5}{c}{ Age group $(y)$} \\
\cline { 3 - 6 }$i=$ & $\operatorname{Pr}(\mathrm{C} i \mid \mathrm{VHL})$ & $<20$ & $21-40$ & $41-60$ & $>60$ \\
\hline 1 & $\operatorname{Pr}($ solitary ocular angioma $\mid \mathrm{VHL})$ & 0.20 & 0.20 & 0.20 & 0.20 \\
2 & $\operatorname{Pr}($ negative parental history $\mid \mathrm{VHL})$ & 0.54 & 0.34 & 0.24 & 0.24 \\
3 & $\operatorname{Pr}($ negative systemic screening $\mid \mathrm{VHL})$ & 0.90 & 0.35 & 0.15 & 0.05 \\
4 & $\operatorname{Pr}($ negative DNA screening $\mid \mathrm{VHL})$ & 0.27 & 0.27 & 0.27 & 0.27 \\
\hline
\end{tabular}

joint molecular genetic and clinical approach, and its prevalence estimated as $9.0 \times 10^{-6}{ }^{4}$ The term $\operatorname{Pr}(\overline{V H L})$ refers to the probability of a person in the population not being affected with VHL disease and this was taken as unity. Substitution of these values gives a probability of underlying VHL disease in a person presenting with a solitary angioma of $29.6 \%$.

However, in the clinic, further information about the patient and their relatives is usually available, including the results of screening for extraocular features of VHL, a parental history, and the results of DNA analysis for VHL gene mutations. The significance of the first two factors in determining the risk of underlying VHL depends on the age of the patient, such that negative findings in an older patient or older parents decreases the likelihood of them being non-penetrant VHL carriers. If DNA analysis were completely sensitive, a negative result would exclude the diagnosis. However, with current DNA screening methods used in most laboratories and the possibilities of mosaicism or non-coding region gene mutations, it is prudent to assume a significant false negative detection rate. To allow for such additional information, we modified the Bayes equation, using the multiplication rule of probability calculus, ${ }^{5}$ as follows:

$\operatorname{Pr}\left(\mathrm{VHL} \mid \mathrm{C}_{1}\right.$ and any combination of $\mathrm{C}_{2}, \mathrm{C}_{3}$ and $\left.\mathrm{C}_{4}\right)=$

$$
\frac{\Pi\left[\operatorname{Pr}\left(C_{i} V H L\right)\right] \times \operatorname{Pr}(V H L)}{\Pi\left[\operatorname{Pr}\left(C_{i} V H L\right)\right] \times \operatorname{Pr}(V H L)+\Pi\left[\operatorname{Pr}\left(C_{i} \mid \overline{V H L}\right)\right] \times \operatorname{Pr}(\overline{V H L})}
$$

This equation represents the probability of underlying VHL given a solitary ocular angioma $\left(C_{1}\right)$ and any combination of: $\mathrm{C}_{2}$, a negative history in the parents for VHL complications, $\mathrm{C}_{3}$, negative systemic screening, and $\mathrm{C}_{4}$, negative DNA analysis, depending on the information available on the patient. $\Pi\left[\operatorname{Pr}\left(C_{i} \mid V H L\right)\right]$ represents the product of the probabilities of a single ocular angioma in a VHL patient and one or more of each of these negative investigations occurring in the presence of VHL disease. These were derived as follows. $\operatorname{Pr}\left(\mathrm{C}_{1} \mid \mathrm{VHL}\right)$ is the probability of a single ocular angioma given VHL is as above. $\operatorname{Pr}\left(\mathrm{C}_{2} \mid \mathrm{VHL}\right)$ is the probability of neither parent of a VHL patient having suffered VHL related complications. This was taken as the sum of the two mutually exclusive probabilities of new mutation and non-pentrance in a VHL patient 20 years older than the subject, taken from the studies of Maher et $a l^{\beta}$ and Maher et al, ${ }^{1}$ respectively. $\operatorname{Pr}\left(\mathrm{C}_{3} \mid \mathrm{VHL}\right)$ is the probability of negative systemic screening given VHL is equivalent to the probability of non-penetrance after systemic investigation. This decreases with increasing age of a VHL gene carrier and values were taken from age of onset data from the study of Maher et al. ${ }^{1} \operatorname{Pr}\left(\mathrm{C}_{4} \mid \mathrm{VHL}\right)$ is the probability of negative DNA analysis for a germline VHL gene mutation in a known VHL carrier was conservatively assumed to be $27 \%$ (using standard PCR and Southern techniques) (unpublished observations and ref 6). These probabilities and their derivation are summarised in table 1 . The probabilities $\operatorname{Pr}\left(C_{i} \mid \overline{V H L}\right)$ represent $\mathrm{i}=1$ the probability of a solitary angioma in a non-VHL subject (above) and $i=2$ to 4 each of the other negative states occurring in a non-VHL person. The latter three probabilities were taken as unity.

Given these calculations, the age related risk estimates for underlying VHL in a patient with a single ocular 
Table 2 Risk estimates for the likelihood of VHL disease given a patient presenting with a single ocular angioma for differing combinations of clinical and molecular information

\begin{tabular}{lllll}
\hline \multirow{2}{*}{ Other negative information } & \multicolumn{4}{c}{ Age group $(y)$} \\
\cline { 2 - 6 } & $<20$ & $21-40$ & $41-60$ & $>60$ \\
\hline None & 0.30 & 0.30 & 0.30 & 0.30 \\
DNA & 0.11 & 0.11 & 0.11 & 0.11 \\
Systemic screening & 0.27 & 0.13 & 0.06 & 0.02 \\
Parental history & 0.19 & 0.13 & 0.09 & 0.09 \\
Parental history + systemic screening & 0.17 & 0.05 & 0.02 & 0.01 \\
DNA + parental history & 0.06 & 0.04 & 0.03 & 0.03 \\
DNA + systemic screening & 0.10 & 0.04 & 0.02 & 0.01 \\
DNA + systemic screening + parental history & 0.06 & 0.01 & $<0.01$ & $<0.01$ \\
\hline
\end{tabular}

angioma after careful ophthalmic examination, and a combination of other negative information, are summarised in table 2 .

Although some caution should be exerted when extrapolating these results to other populations (for example, the mutation detection sensitivity will depend on the precise investigations performed and the prevalence of sporadic ocular angioma might vary), this analysis does, for the first time, provide clinicians with risk estimates for the likelihood of underlying systemic disease in patients with a solitary ocular angioma. This information will help deter- mine the most appropriate investigation and management of such patients.

We gratefully acknowledge the Guide Dogs for the Blind Association and the TFC Frost Trust for support and Dr C Bunce for advice.

ANDREW R WEBSTER* EAMONN R MAHER $†$ ALAN C BIRD*

${ }^{\star}$ Moorfields Eye Hospital, London, UK ANTHONY T MOORE^

tSection of Medical and Molecular Genetics, Department of Paediatrics and Child Health, University of Birmingham, UK

$\ddagger$ Ophthalmology Department, Addenbrooke’s Hospital, Cambridge, UK

1 Maher ER, Yates JRW, Harries R, Benjamin C, Harris R, Ferguson-Smith MA. Clinical features and natural history of von Hippel-Lindau disease. $Q$ 7 Med 1990;77:1151-63.

2 Webster AR, Moore AT, Maher ER. The clinical characteristics of ocular angiomatosis in von Hippel Lindau disease and correlation with germline mutation. Arch Ophthalmol 1999;117:371-8.

3 Maher ER, Iselius L, Yates JR, et al. Von Hippel-Lindau disease: a genetic study. F Med Genet 1991;28:443-7.

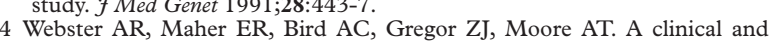
Webster AR, Maher ER, Bird AC, Gregor ZJ, Moore AT. A clinical and
molecular genetic analysis of solitary ocular angioma. Ophthalmology 1999; 106:623-9.

5 Rosner B. Fundamentals of biostatistics. 4th ed. Chapter 5. London: Wadsworth, 1995.

6 Maher ER, Webster AR, Richards et al. Phenotypic expression in von Hippel-Lindau disease: correlations with germline VHL gene mutations. $\mathcal{F}$ Med Genet 1996;33:328-32.

\section{Confirmation of the assignment of the Sanjad-Sakati (congenital hypoparathyroidism) syndrome (OMIM 241410) locus to chromosome lq42-43}

EDITOR-Over the past 12 years, 26 patients with an unusual syndrome of congenital hypoparathyroidism associated with severe prenatal and postnatal growth retardation and a pattern of facial anomalies have been seen at the King Faisal Specialist Hospital and Research Centre, Saudi Arabia. $^{12}$ The disorder has been listed by McKusick in OMIM as "hypoparathyroidism-retardation-dysmorphism syndrome; HRD" as entry 241410. Recently, Parvari et al reported the assignment of the gene for this disorder to chromosome 1 at $1 \mathrm{q} 42-43$. Their report was based on a study of consanguineous Bedouin families from Israel and their linkage analysis was based on homozygosity by descent. ${ }^{4}$ This reports describes a study of three consanguineous Saudi families, which yielded results consistent with the 1q42-43 location of the responsible gene.

Blood samples were collected and DNA extracted from three Saudi families consisting of first cousin parents and their 14 children, five of whom manifested the SanjadSakati syndrome. DNA samples were pooled from the five affected children and a separate pooled sample prepared from the DNA of their nine unaffected sibs. The initial analysis included PCR amplified DNA markers linked to genes involved either in parathyroid structure or function. ${ }^{5}$ As no evidence of linkage was found, the analysis was expanded to the human genome screening set from Research Genetics (Huntsville, Alabama). The analysis proceeded from chromosome 22 to chromosome 1. A positive result was based on finding a single band in the pooled sample from the affected children indicating homozygosity, while the pooled sample from the unaffected sibs showed two or more bands. A positive result with marker D1S235 prompted analysis of all 20 samples separately with the additional markers D1S1656, D1S163, D1S179, D1S2712，D1S1540，D1S1680, D1S2678, D1S2680, D1S2850, D1S373, and D1S2670, all of which cluster around 1q42-43.

Multipoint lod scores were generated using MAPMAKER/HOMOZ. ${ }^{6}$ Analysis of the data assumed equal frequencies of the alleles at each marker. The order of the markers was taken from the maps published by Broman et al. $^{7}$ The data showed that the affected sibs in the three families were homozygous for markers that clustered around the marker D1S235. A maximum lod score of 4.12 around D1S235 at 1q42-43 was obtained. Flanking markers D1S1656 and D1S2678 were consistent with those found by Parvari et $a l^{\beta}$ and suggest a candidate region maximally at $1 \mathrm{cM}$.

The initial report of Sanjad et $a l^{1}$ in 1988 and their definitive report in $1991^{2}$ clearly established this as a distinct disorder with autosomal recessive inheritance. The consistency with which hypocalcaemic tetany or seizures or both occur in intrauterine growth retarded infants suggests that this is not a diagnosis likely to be missed. That this disorder has only been reported in consanguineous Arabic families suggests that a founder effect of a long standing mutation is responsible for this disorder.

Kenny-Caffey syndrome type 1 is clinically manifest as growth retardation, craniofacial anomalies, small hands and feet, hypocalcaemia, hypoparathyroidism, and radiological evidence of cortical thickening in the long bones with medullary stenosis and absent diploic space in the skull. The original reports of $\mathrm{Caffey}^{8}$ and Kenny and Linarelli ${ }^{9}$ suggested autosomal dominant inheritance and the condition is now referred to as Kenny-Caffey syndrome type 2. In 1997 Khan et $a l^{10}$ reported on 16 affected children with Kenny-Caffey syndrome type 1 in six unrelated sibships born to healthy, consanguineous, Bedouin parents from Kuwait. From this group of patients, Diaz et $a l^{11}$ in 1998 mapped the locus for this disorder to 1q42-43. All of this information taken together suggests 
that the Sanjad-Sakati syndrome and type 1 Kenny-Caffey syndrome are at least allelic disorders if not the same condition. Despite the multiplicity of abnormalities, including intrauterine growth retardation, mental retardation, and facial dysmorphism with congenital hypoparathyroidism, there is currently no information about the nature of the underlying molecular defect in either disorder. Mapping of the locus responsible now offers promise for analysis of candidate genes or positional cloning as likely methods to delineate the molecular basis.

THADDEUS E KELLY SUSAN BLANTON

Division of Medical Genetics, University of Virginia School of Medicine, Charlottesville, Virginia 22908, USA

RAMLA SAIF SAMI A SANJAD NADIA A SAKATI

Department of Pediatrics, King Faisal Specialist Hospital and Research Centre, Riyadh, Saudi Arabia

1 Sanjad SA, Sakati NA, Abu-Osba YK. Congenital hypoparathyroidism with dysmorphic features: a new syndrome. Pediatr Res 1988:22A
2 Sanjad SA, Sakati NA, Abu-Osba YK, Kaddoura R, Milner RDG. A new syndrome of congenital hypoparathyroidism, severe growth failure and dysmorphic features. Arch Dis Child 1991;66:193-6.

3 Parvari R, Hershkovitz E, Kanis A, et al. Homozygosity and linkage disequilibrium mapping of the syndrome of congenital hypoparathyroidism, growth and mental retardation, and dysmorphism to a 1-cM interval of chromosome 1. Am f Hum Genet 1998;63:163-9.

4 Lander ES, Botstein D. Homozygosity mapping: a way to map human recessive traits with the DNA of inbred children. Science 1987;236:1567-70.

5 Shashi V, Golden WL, Allinson PS, Kelly TE. Molecular analysis of recombination in a family with a large pericentric X-chromosome inversion. Am $\mathcal{F}$ Hum Genet 1998;58:1231-8.

6 Kruglyak L, Daly MJ, Lander ES. Rapid multipoint linkage analysis of recessive traits in nuclear families, including homozygosity mapping. $\mathrm{Am} \mathcal{f}$ Hum Genet 1995;56:519-27.

7 Broman KW, Murray JC, Sheffield VC, White RL, Weber JL. Comprehensive human genetic maps: individual and sex-specific variation in recombination. Am $\mathcal{7}$ Hum Genet 1998;63:861-9.

8 Caffey J. Congenital stenosis of medullary spaces in tubular bones and calvaria in two proportional dwarfs - mother and son coupled with transitory hypocalcemic tetany. AfR 1967;100:1-11.

9 Kenny FM, Lineralli L. Dwarfism and cortical thickening of tubular bones: transient hypocalcemia in mother and son. Am $\mathrm{f}$ Dis Child 1985;111:201-7.

10 Khan KTS, Uma R, Usha R, Al Ghanem MM, Al Awadi SA, Farag TI. Kenny-Caffey syndrome in six Bedouin sibships: autosomal recessive inheritance is confirmed. Am $\mathcal{7}$ Med Genet 1997;69:126-32.

11 Diaz GA, Khan KTS, Gelb BD. The autosomal recessive Kenny-Caffey syndrome locus maps to chromosome 1q42-43. Genomics 1998;54:13-18.

\section{Molecular diagnosis is important to confirm suspected pseudoachondroplasia}

EDITOR-Pseudoachondroplasia (PSACH) is an autosomal dominant chondrodysplasia. In the majority of clinically defined cases, mutations have been identified in the gene encoding cartilage oligomeric matrix protein $(C O M P) .{ }^{1}$ Mutations in the COMP gene have also been identified in some forms of multiple epiphyseal dysplasia (MED), a related skeletal dysplasia. ${ }^{1}$ All of the mutations associated with PSACH and MED have been found in exons encoding the type III repeat region or C-terminal domain of COMP.

Clinically, PSACH is characterised by short limbed dwarfism, which first becomes apparent in infancy, short fingers, ligamentous laxity, scoliosis, and early onset osteoarthritis (OA). ${ }^{2}$ Radiographic features include small irregular epiphyses with delayed ossification, flared metaphyses, anterior beaking of the vertebral bodies, and delayed maturation of the triradiate cartilage and acetabulum. ${ }^{3}$

We report three patients who had previously been given erroneous diagnoses, in whom mutations in exon 13 of the COMP gene have been identified. This emphasises the utility of molecular diagnosis, particularly in adult patients where radiological diagnosis can be difficult.

All three affected subjects were born to unaffected parents. Each was of normal intelligence and normal facial appearance.

Case 1 presented at 5 years because of pain in both hips. Numerous diagnoses, including spondyloepiphyseal dysplasia congenita with coxa vara and Morquio's syndrome, were considered following $x$ ray examination. Extensive surgery over the following years included a left femoral osteotomy and bilateral Girdlestones operations to treat her osteoarthritis. She has had two unaffected children. Examination at 65 years showed her height at $136 \mathrm{~cm}$ ( $<3$ rd centile), reduced extension at the elbows, short, stubby fingers, and severe kyphosis. Radiological examination showed rhizomelic limb shortening, a prominent deltoid insertion, brachydactyly, metaphyseal broadening, extensive degenerative changes of the knee and elbow, femoral head destruction with formation of pseudoacetabula superiorly bilaterally, a thoracolumbar kyphosis with anterior wedging of the lower thoracic vertebral bodies, and a horizontal sacrum.

Case 2 first presented at 3 years with short stature $(87.5$ $\mathrm{cm},<3 \mathrm{rd}$ centile) and bowed legs. Clinical and radiological examination suggested a diagnosis of spondylometaphyseal dysplasia type Kozlowski. Eight operations had been performed to effect tibial lengthening and straightening. Examination at 16 years showed a height of $124 \mathrm{~cm}(<3 \mathrm{rd}$ centile), genu varum, a waddling gait, and short stubby fingers. $X$ ray appearances showed ovoid vertebral bodies, epiphyseal involvement, hypoplasia of the iliac bone, splayed irregular metaphyses, and evidence of the multiple operations, with pins and a plate in situ.

Case 3, a 36 year old woman initially presented at 18 months with an intermittent limp. Radiological assessment at this time was normal. Referral at 9 years for investigation of bilateral hip and left knee pain confirmed short stature, $107 \mathrm{~cm}$ (<3rd centile), with rhizomelic limb shortening, short fingers, and a waddling gait. Radiological assessment showed abnormal epiphyses and metaphyses, but normal vertebral bodies. At this time diagnoses of multiple epiphyseal dysplasia, PSACH, and Morquio's syndrome were all considered. At 21 years she had surgery to correct a subluxated left patella. She was recently referred to our department with a diagnosis of achondroplasia. She is awaiting bilateral total hip replacements for treatment of osteoarthritis. Examination showed a height of $125.5 \mathrm{~cm}$ ( $<3$ rd centile), short fingers, mild ligamentous laxity, and a waddling gait. $X$ ray appearances showed marked epiphyseal involvement of the knees, hips, and wrists bilaterally, anterior beaking of the vertebral bodies, and metaphyseal changes in the metacarpals.

All three cases presented during infancy, had height below the 3rd centile, and rhizomelic limb shortening, normal skulls, and short, stubby fingers. Cases 1 and 3 both had severe osteoarthritis affecting their hips bilaterally and necessitating surgery. Case 1 also had a severe dorsolumbar kyphosis and case 2 genu varum. The features are all within the recognised spectrum associated with PSACH and although radiological investigations were compatible with this diagnosis they were not definitive. Previous $x$ rays 
taken in childhood were not available from the three patients. In view of this, the clinical presentation, and the previous difficulty in diagnosis, molecular confirmation was sought.

Mutation screening in exons of the COMP gene using SSCP and sequence analysis has been described previously. ${ }^{1}$ In addition to mutation screening in genomic DNA from all three patients, we also screened for a COMP mutation in RNA isolated from a skin fibroblast cell line established on case 3. In this instance, cDNA was PCR amplified using primers flanking the type III repeat region and C-terminal domain of COMP. The oligonucleotide primers used were CaMF (5'-ggt cgc gac act gac cta gac-3') and CaMR (5'-ggt gag cgt gac ttc cag cgt t-3'), which amplified a 789 bp fragment containing the entire type III repeat region, and $\mathrm{CtF}$ (5'-gaa gtc acg ctc acc gac-3') and CtR (5'-cta ggc ttg ccg cag ctg atg g-3'), which amplified a 702 bp fragment containing the entire C-terminal domain.

Each patient was found to have a mutation in exon 13 of COMP. Case 1 was heterozygous for an in frame $3 \mathrm{bp}$ deletion of GAG between nucleotides 1394-1397, which is predicted to result in the deletion of glutamic acid at residue 457 . Case 2 was found to be heterozygous for an in frame $3 \mathrm{bp}$ deletion of GAC between nucleotides 1430-1444, which is predicted to result in the deletion of an aspartic acid residue from between residues 469-473. Case 3 was found to be heterozygous for a $\mathrm{G}$ to $\mathrm{T}$ transversion at nucleotide 1418 , which is predicted to result in the substitution of glycine by serine at residue 465 . All of the mutations affect residues within the seventh repeat of the type III repeat region and are predicted to result in a qualitative defect in the COMP protein. The in frame deletion of one or more residues from the type III repeats of COMP have been described previously. ${ }^{1}$ The G465S substitution affects a highly conserved glycine residue and the substitution of equivalent glycine residues in the second, fourth, and sixth type III repeats have previously been identified in patients with PSACH. Previous work has determined that in approximately $40 \%$ of cases of PSACH, deletion mutations in exon 13 of the COMP gene are responsible. ${ }^{1}$ Our work (present study and M D Briggs, unpublished data) suggests that approximately $50 \%$ of all PSACH results from various mutations, either deletions/duplications or point mutations, in exon 13 of the COMP gene and we propose that analysis of this exon would be an appropriate initial step in the evaluation of a patient with suspected PSACH. We have also shown that it is possible to screen for COMP gene mutations in $\mathrm{mRNA}$ isolated from skin fibroblast cell lines using RT-PCR. This approach will allow for the rapid screening of mutations and used in conjunction with genomic analysis of the COMP gene will help provide molecular diagnosis to confirm a clinically suspected diagnosis of PSACH.

Diagnosis of PSACH has previously been based on the clinical assessment and the characteristic radiological features of people with short stature. These three cases show the difficulty in making a definitive diagnosis of PSACH in the absence of molecular confirmation. Accurate diagnosis is important, not only so that reproductive options may be considered in an informed context, but also so that accurate information about the prognosis of the condition may be provided. ${ }^{4}$ In case 1 the erroneous differential diagnoses had been made 50 years ago and had not been re-evaluated in the interim, despite the improved and expanded classification of the skeletal dysplasias. Molecular diagnosis can be especially helpful in adulthood when radiological diagnosis is more difficult owing to concomitant changes resulting from osteoarthritis.

This work was supported by grants from the Arthritis Research Campaign (MDB is an ARC Post-Doctoral Research Fellow) and Wellcome Trust (BN is a Wellcome Trust Clinical Training Fellow).

\section{B NEWMAN ${ }^{\star}+$ D DONNAI + M D BRIGGS*}

*Wellcome Trust Centre for Cell-Matrix Research, School of Biological Sciences, 2.205 Stopford Building, University of Manchester, Oxford Road, Manchester M13 9PT, UK

†University Department of Medical Genetics and Regional Genetic Service, St Mary's Hospital, Hathersage Road, Manchester, M13 0fH, $U K$

1 Briggs MD, Mortier GR, Cole WG, et al. Diverse mutations in the gene for cartilage oligomeric matrix protein in the pseudoachondroplasia-multiple
epiphyseal dysplasia disease spectrum. Am 7 Hum Genet 1998;62:311-19. 2 Wynne-Davies R, Hall CM, Young ID. Pseudoachondroplasia: clinical diag2 Wynne-Davies R, Hall CM, Young ID. Pseudoachondroplasia: clinical diag-
nosis at different ages and comparison of autosomal dominant and recessive types. A review of 32 cases (26 kindreds). 7 Med Genet 1986;23:425-34.

3 Crossan JF, Wynne-Davies R, Fulford GE. Bilateral failure of the capital femoral epiphysis: bilateral Perthes disease, multiple epiphyseal dysplasia, pseudoachondroplasia and spondyloepiphyseal dysplasia congenita and tarda. F Pediatr Orthop 1983;3:297-301

4 McKeand J, Rotta J, Hecht JT. Natural history study of pseudoachondroplasia. Am F Med Genet 1996;63:406-10.
EDITOR-Silver-Russell syndrome (SRS) is a condition characterised by intrauterine and postnatal growth retardation with relative sparing of cranial growth, triangular facies, fifth finger clinodactyly, and facial, limb, or truncal asymmetry. ${ }^{2}$ The molecular basis of SRS remains elusive and seems likely to be heterogeneous. However, maternal uniparental disomy of chromosome 7 (mUPD7) has been found in approximately $10 \%$ of SRS patients, suggesting that at least one gene on chromosome 7 is imprinted and involved in the pathogenesis of this condition. ${ }^{3}$ Interest has surrounded the human chromosomal region $7 \mathrm{p} 12-13$, which is homologous to mouse proximal chromosome 11 , f Med Genet 2000;37:65-67

since mUPD for this region in mice leads to prenatal growth failure. ${ }^{5}$ Within this region lie the genes for insulinlike growth factor binding proteins 1 and 3 (IGFBP1 and $I G F B P 3)$. Both are involved in regulation of fetal growth via the insulin-like growth factor axis. ${ }^{6} I G F B P 1$ and $I G F B P 3$ are therefore obvious candidates for a role in the SRS phenotype associated with mUPD $7 .^{34}$

In order to determine whether IGFBP1 and/or IGFBP3 are likely to be implicated in SRS, we have investigated their imprinting status in normal fetal tissues collected from termination of pregnancies. Samples were obtained from Queen Charlotte's and Chelsea Hospital with the approval of the Research Ethics Committee of the Royal Postgraduate Medical School (96/4955) and from the MRC Tissue Bank at Hammersmith Hospital (L Wong). Genomic DNA and total RNA was extracted from these tissues and RT-PCR performed as previously described. ${ }^{7}$ The primers used in this study are listed in table 1. PCR was carried out for 35 cycles for all reactions. Products 
were sequenced on an ABI PRISM 377 automated DNA sequencer using the dRhodamine Ampli-Taq dyeterminator cycle sequencing kit, according to the manufacturer's instructions.

Since fetal IGFBP1 expression is highly tissue specific, ${ }^{8}$ its imprinting status was only investigated in fetal liver. Primers IGFBP1-BF and -ER were designed to span an expressed polymorphism at nucleotide 5772 within exon 4 (Genbank accession: M59316). ${ }^{9}$ These primers were used to screen genomic DNA from 16 first and second trimester fetuses. Five were identified as being heterozygous for the polymorphism and thus informative. Their gestational ages ranged from 5 to 17 weeks. Primers IGFBP1-EF and -ER, which span introns 2 and 3, were used to amplify liver cDNA derived from these informative fetuses. Control samples prepared from liver RNA without the addition of reverse transcriptase (RT) were also amplified. No genomic contamination was observed in any of the samples. RT-PCR products were sequenced using the reverse primer IGFBP1-ER and biallelic expression was seen in all five cases (fig 1 ).

An expressed polymorphism, consisting of an adenine insertion at nucleotide position 10049 (Genbank accession: M35878) within the 3' untranslated region of IGFBP3 (Dr I Morison, personal communication), was used to study the parental origin of expression in this gene. Primers IGFBP3-EF and -ER, from within exon 5, span this polymorphism and were used to screen fetal genomic DNA. The heterozygosity for this sequence change was $21 \%$, with the adenine insertion being the most frequent allele in a UK based population. A total of 21 samples were screened and three heterozygous fetuses of 8-10 weeks' gestation were identified. Paired maternal DNA was homozygous in each case. Since IGFBP3 is widely expressed, ${ }^{8}$ parental allele expression was examined in brain, placenta, limb, and skin from all three fetuses. cDNA was amplified by RT-PCR using primers IGFBP3-GF and -ER which span intron 4 . RT-PCR products were sequenced in both forward and reverse directions. Absence of genomic contamination was confirmed by using RT negative control samples and by sequencing RT-PCR products across the boundary of intron

Table 1 Oligonucleotide primers used to investigate the imprinting status of IGFBP1 and 3

\begin{tabular}{lllll}
\hline $\begin{array}{l}\text { Gene } \\
\text { (Genbank No) }\end{array}$ & Primer name & Primer sequence (5'-3') & $\begin{array}{l}\text { Annealing } \\
\text { temp }\left({ }^{\circ} \mathrm{C}\right)\end{array}$ & $\begin{array}{l}\text { Nucleotide } \\
\text { Nos }\end{array}$ \\
\hline IGFBP1 & IGFBP1-BF & gtctacccttggaatgggaa & 55 & $5704-5723$ \\
$($ M59316) & IGFBP1-EF & ggagctctggataatttcca & 57 & $3304-3324$ \\
& IGFBP1-ER & tatggagtataaaaagtagttact 55/57 & $5898-5921$ \\
IGFBP3 & IGFBP3-EF & aggtggagtcctacttgttt & 55 & $9872-9891$ \\
(M35878) & IGFBP3-GF & tgctacagcatgcagagc & 55 & $8315-8332$ \\
& IGFBP3-ER & tacattgtgctaaggaggac & 55 & $10211-10230$ \\
& IGFBP3-F & ctacgagtctcagagcacag & 57 & $5890-5909$ \\
& IGFBP3-R & ctgcatgctgtagcagtgca & 57 & $8310-8329$ \\
\hline
\end{tabular}

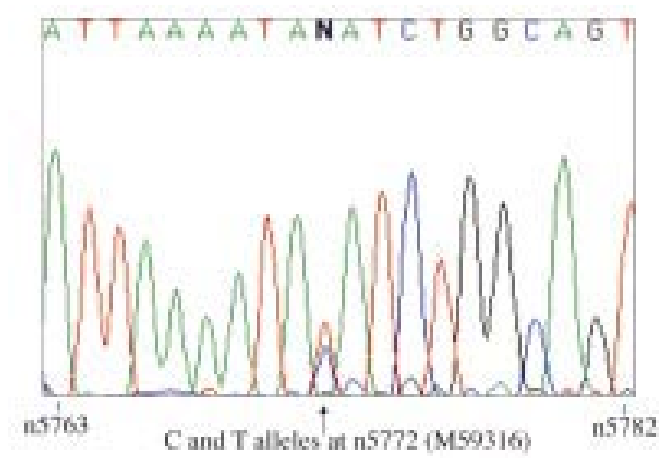

Figure 1 Biallelic expression of IGFBP1 in liver from one 12 week heterozygous fetus. Sequence is shown in the reverse complement direction and the polymorphic site is indicated by an arrow.
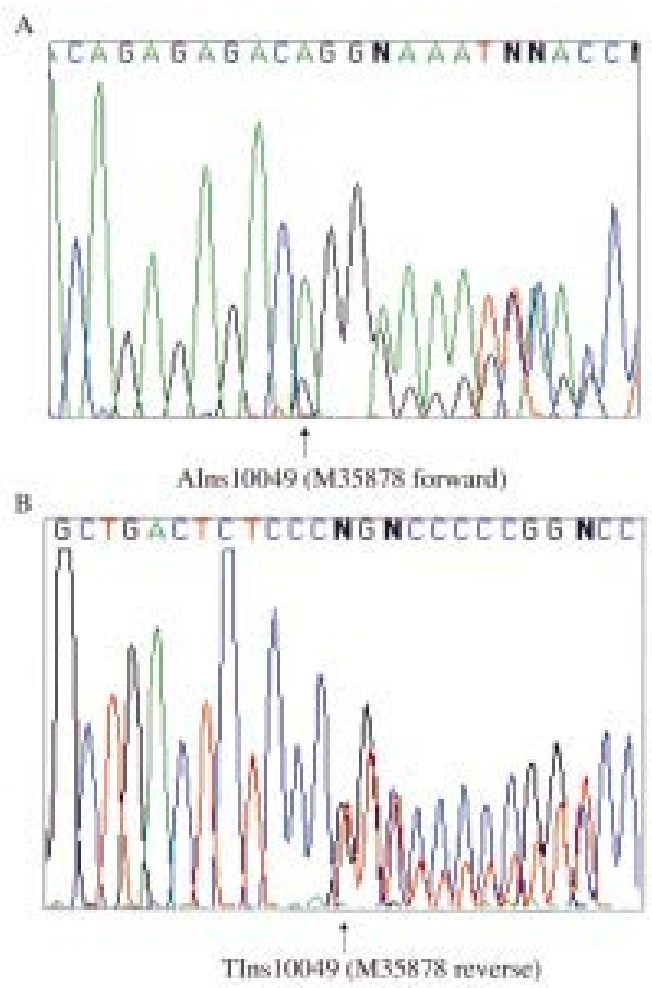

Figure 2 Biallelic expression of IGFBP3 in brain from one 10 week heterozygous fetus. Sequence is shown in both the forward $(A)$ and reverse (B) directions. The polymorphic site is indicated by arrows.

4. Both parental alleles were detected in every tissue examined for all three fetuses (fig 2).

The expression of IGFBP3 was also investigated in fibroblast and transformed lymphoblast cells from SRS patients. RNA was obtained from two normal subjects, two SRS patients with mUPD7, and four SRS patients without mUPD7. IGFBP3 mRNA expression was studied by RT-PCR using primers IGFBP1-F and -R. Products of the expected size (301 bp) were seen in UPD and non-UPD patients, as well as in the normal controls (data not shown). Similar results were obtained using transformed lymphoblast cells. Since IGFBP1 expression was not detectable in either transformed lymphoblasts, lymphocytes, or fibroblasts, mRNA in mUPD7 patients could not be similarly investigated. However, IGFBP1 and IGFBP3 were both present in the serum of the two mUPD7 patients at normal levels.

These results show that in fetal tissues both IGFBP1 and $I G F B P 3$ are biallelically expressed. Expression of IGFBP3 in fibroblasts and lymphoblasts from patients with mUPD7 also rules out paternal specific expression of this gene in these cells in childhood. Although the expression of IGFBP1 could not be directly investigated in SRS patient cell lines, because of its tissue specificity, serum levels in mUPD7 patients were normal. We therefore found no evidence for imprinting of $I G F B P 1$ or $I G F B P 3$, making their involvement in SRS unlikely.

Tissue and developmental stage specific imprinting is being reported in an increasing number of genes including KCN8 (KvLQT1), IGF2, CDKN1C ( $p 57^{K i p 2}$ ), UBE3A, and $M E S T .{ }^{10}$ These make absolute exclusion of a gene as a candidate, on the basis of lack of observable monoallelic expression, difficult. Allelic expression of IGFBP1 and $I G F B P 3$ was investigated during the fetal period and in tissues that were predicted to be biologically relevant. However, the possibility of imprinting of either gene in a particular cell type or restricted window of time could not 
be ruled out. Although fetuses of up to 18 weeks' gestation were screened for IGFBP3 heterozygosity, the latest stage at which an informative fetus was identified was 10 weeks gestation. Demonstration of IGFBP3 biallelic expression was therefore limited to the first trimester.

Quantitative analysis was attempted using SSCP analysis but neither polymorphism could be detected by this method. As the relative level of transcripts from the two alleles was not determined, preferential expression from one parental allele in either gene was not excluded.

Contamination by maternal tissue could potentially obscure an imprinting effect in fetal samples. For tissues used to study IGFBP3 expression, paired maternal blood samples were available. All three maternal samples from heterozygous fetuses were found to be homozygous for the polymorphism studied. Maternal specific expression could therefore not have been missed. Although it is possible that maternal contamination of fetal tissue is obscuring paternal specific expression, the demonstration of biallelic expression in all samples studied makes this unlikely. Paired maternal tissue was not available for fetal liver tissues used in the study of IGFBP1. However, the consistent observation of both alleles in five different samples makes it unlikely that monoallelic expression is being masked by maternal contamination.

Several other candidates for SRS have already been excluded. The involvement of IGF1R in SRS is unlikely since no hemizygosity or mutations were found for this gene in a cohort of 33 SRS patients. ${ }^{11}$ Riesewijk et al ${ }^{12}$ have also failed to find evidence for a role of MEST, an imprinted gene located at $7 \mathrm{q} 32$. Two other candidates lie close to IGFBP1 and IGFBP3 in the region $7 \mathrm{p} 12-13$. $E G F R$ is biallelically expressed and therefore unlikely to play a role in SRS. ${ }^{6}$ GRB10 is homologous to mouse Meg1/ Grb10, a gene recently identified in a systematic screen for maternally expressed imprinted genes by subtraction hybridisation. ${ }^{13}$ The imprinting status of GRB10 in man remains to be determined and its role in SRS is currently under investigation. Since imprinted genes tend to be located in clusters, it is likely that other imprinted genes lie within the regions surrounding MEST and probably, also, GRB10. These regions remain of interest in the search for candidate genes for SRS.
We thank the medical staff at Queen Charlotte's Hospital for help collecting samples and Sue Blunt from the cytogenetics laboratory for culturing fibroblast cells. This work was supported by funding from Action Research (EW), The Dunhill Medical Trust (SA), and Children Nationwide and Pharmacia and Upjohn $(\mathrm{MH})$. Information regarding the IGFBP3 polymorphism was obtained from Dr I Morison, Department of Biochemistry, University of Otago, New Zealand.

EMMA L WAKELING ${ }^{\star}+$ MEGAN P HITCHINS* + SAYEDA N ABU-AMERO* PHILIP STANIER* GUDRUN E MOORE* MICHAEL A PREECE ${ }^{\star} \dagger$

*Action Research Laboratory for the Molecular Biology of Fetal

Development, Division of Paediatrics, Obstetrics and Gynaecology, Imperial College School of Medicine, Queen Charlotte's and Chelsea Hospital, Goldhawk Road, London W6 OXG, UK

†Institute of Child Health, University College London, 30 Guilford Street, London WC1N 1EH, UK

Correspondence to: Dr Wakeling, e.wakeling@ic.ac.uk

1 Silver HK, Kiyasu W, George J, Deamer WC. Syndrome of congenital hemihypertrophy, shortness of stature, and elevated urinary gonadotrophins. Pediatrics 1953;12:368-76.

2 Russell A. A syndrome of intrauterine dwarfism recognizable at birth with craniofacial dysostosis, disproportionate short arms and other anomalies. Proc R Soc Med 1954;47:1040-4.

3 Kotzot D, Schmitt S, Bernasconi F, et al. Uniparental disomy 7 in Silver-Russell syndrome and primordial growth retardation. Hum $\mathrm{Mol}$ Genet 1995;4:583-7.

4 Preece MA, Price SM, Davies V, et al. Maternal uniparental disomy 7 in Silver-Russell syndrome. 7 Med Genet 1997;34:6-9.

5 Beechey CV, Cattanach BM. Genetic imprinting map. Mouse Genome 1997; 95:54-5.

6 Jones J, Clemmons D. Insulin-like growth factors and their binding proteins: biological actions. Endocr Rev 1995;16:3-34.

7 Wakeling EL, Abu-Amero SN, Stanier P, Preece MA, Moore GE. Human $E G F R$, a candidate gene for the Silver-Russell syndrome, is expressed in a wide range of fetal tissues. Eur F Hum Genet 1998;6:158-64.

8 Han VKM, Matsell DG, Delhanty PJD, Hill DJ, Shimasaki S, Nygard K. IGF-binding protein mRNAs in the human fetus: tissue and cellular distribution of developmental expression. Horm Res 1996;45:160-6.

9 Ehrenborg E, Larsson C, Stern I, Janson M, Powell DR, Luthman H. Contiguous localisation of the genes encoding human insulin-like growth factor tiguous localisation of the genes encoding human insulin-like growth factor

10 Morison IM, Reeve AE. A catalogue of imprinted genes and parent-oforigin effects in humans and animals. Hum Mol Genet 1998;7:1599-609.

11 Abu-Amero S, Price S, Wakeling E, et al. Lack of hemizygosity for the insulin-like growth factor 1 receptor gene in a quantitative study of 33
Silver-Russell syndrome probands and their families. Eur f Hum Genet Silver-Russell sync

12 Riesewijk AM, Blagitko N, Schinzel AA, et al. Evidence against a major role of PEG1/MEST in Silver-Russell syndrome. Eur f Hum Genet 1998;6:11420

13 Miyoshi N, Kuroiwa Y, Kohda T, et al. Identification of the Meg1/Grb10 imprinted gene on mouse proximal chromosome 11, a candidate for the Silver-Russell syndrome gene. Proc Natl Acad Sci USA 1998;95:1102-7.

\section{Mutational analysis of the human pancreatic secretory trypsin inhibitor (PSTI) gene in hereditary and sporadic chronic pancreatitis}

EDITOR-Hereditary pancreatitis (HP) is an autosomal dominant disease with about $80 \%$ penetrance that mainly afflicts white families. ${ }^{1}$ Although pancreatitis was hypothesised to result from inappropriate activation of pancreatic zymogens by Chiara ${ }^{2}$ in 1896, and the genetic nature of HP was identified by Comfort et $a \beta^{3}$ in 1952, the precise mechanism underlying the pathogenesis of HP has remained a mystery until recently. By familial linkage analysis, a genetic defect was mapped to chromosome $7 \mathrm{q} 35$ by Le Bodic et al, ${ }^{4}$ and independently confirmed by two other groups in $1996 .{ }^{56}$ Soon after, a single $\mathrm{G}$ to A mutation resulting in an arginine $(\mathrm{R})$ to histidine $(\mathrm{H})$ substitution $(\mathrm{R} 117 \mathrm{H})$ in the third exon of the cationic trypsinogen gene was identified as being associated with HP by Whitcomb et al. ${ }^{7}$

Trypsinogen is synthesised in the acinar cells of the pancreas and is activated into trypsin upon cleavage of the activation peptide by enterokinase. Trypsin plays a central role in pancreatic exocrine physiology by acting as the trigger enzyme which leads to the activation of all the pancreatic digestive proenzymes as well as trypsinogen itself. When the $\mathrm{R} 117 \mathrm{H}$ mutation was identified, Whitcomb et al ${ }^{7}$ concluded that this mutation did not affect the tertiary structure of trypsin, nor alter its catalytic activity or interfere with trypsin inhibitor binding, since the three dimensional position of R117 was located on the opposite surface of the trypsin molecule to the catalytic and trypsin inhibitor binding sites. They hypothesised instead that the $\mathrm{R} 117 \mathrm{H}$ mutation eliminated a "fail safe" mechanism for the inactivation of trypsin by abolishing an important autolytic site. Thus, the stabilised mutant enzyme would disrupt the trypsin activation/inhibition balance and trigger the pancreatic autodigestion process which results in pancreatitis under certain conditions. This model coincided 
Table 1 Primers, conditions for DGGE analysis, and DNA variants detected in the human PSTI gene

\begin{tabular}{|c|c|c|c|c|c|c|c|}
\hline \multirow[b]{2}{*}{ Scanning region } & \multirow[b]{2}{*}{ Primer sequence $\left(5^{\prime} \rightarrow 3^{\prime}\right)$} & \multirow[b]{2}{*}{$\operatorname{Temp}\left({ }^{\circ} \mathrm{C}\right)$} & \multirow[b]{2}{*}{$\begin{array}{l}\text { Length of } \\
\text { amplicon }\end{array}$} & \multicolumn{2}{|l|}{$D G G E$} & \multirow[b]{2}{*}{$\begin{array}{l}\text { DNA variants } \\
\text { detected }\end{array}$} & \multirow[b]{2}{*}{$\begin{array}{l}\text { Frequency } \\
\text { of allelet }\end{array}$} \\
\hline & & & & $\begin{array}{l}\text { Gradient } \\
\text { range (\%) }\end{array}$ & $\begin{array}{l}\text { Migration } \\
\text { time }(h)\end{array}$ & & \\
\hline$-334 \sim-103$ & $\begin{array}{l}\text { TTTGAGTTCATCTTACAGGTGAG } \\
\text { AGGGTCATATGGCAGATGGCAGCAA }\end{array}$ & 57 & 317 & $20-70$ & 8 & $-253 \mathrm{~T}>\mathrm{C}$ & $24 / 118$ \\
\hline $\begin{array}{l}-117 \sim-1 \\
+ \text { Exon } 1\end{array}$ & $\begin{array}{l}\text { CCAGGGAGATCTGTGATATAGC } \neq \\
\text { CAGTTTTATTTAAATTTGAA }\end{array}$ & 50 & 266 & $50-100$ & 8 & $\begin{array}{l}-41 \mathrm{G}>\mathrm{A} \\
-22 \mathrm{C}>\mathrm{T}\end{array}$ & $\begin{array}{l}0 / 400 \\
2 / 400\end{array}$ \\
\hline Exon 2 & $\begin{array}{l}\text { AAGAAGTCACAGTCTGCAATGAAAG } \\
\text { CGGTGACAGCAAGGCTGCAATTTT }\end{array}$ & 67 & 247 & $40-70$ & 9 & IVS $1-37 \mathrm{~T}>\mathrm{C}$ & $2 / 120$ \\
\hline Exon 3 & $\begin{array}{l}\text { ATTTGCTATGAACTCAAGAATGG } \\
\text { AACTAACTTAAAATATATAGTTTA }\end{array}$ & 54 & 254 & $20-70$ & 8 & $\begin{array}{l}\text { c. } 101 \mathrm{~A}>\mathrm{G}(\mathrm{N} 11 \mathrm{~S}) \\
\text { c. } 163 \mathrm{C}>\mathrm{T}(\mathrm{P} 32 \mathrm{~S}) \\
\text { c. } 174 \mathrm{C}>\mathrm{T}(\mathrm{C} 35 \mathrm{C})\end{array}$ & $\begin{array}{l}3 / 400 \\
2 / 400 \\
0 / 400\end{array}$ \\
\hline Exon 4 & $\begin{array}{l}\text { TTTCATCAGTGAAGTTTAAGCTGATA } \\
\text { CGCGGTGACCTGATGGGATTT } \ddagger\end{array}$ & 62 & 167 & $20-70$ & 8 & NDS & \\
\hline
\end{tabular}

^Total length including a 40 bp GC clamp.

tFrequency evaluated in control chromosomes.

†A 40 bp GC clamp was attached to the 5 ' end of the primer.

$§$ Not detected.

with Chiara's pancreatitis hypothesis ${ }^{2}$ and has been supported by in vitro mutagenesis data. When the R117 of rat trypsin was replaced by other amino acids, the rate of autolysis of certain mutant enzymes was significantly slower than that of the wild type protein. ${ }^{89}$ While the $\mathrm{R} 117 \mathrm{H}$ mutation has been shown to be a common mutation in HP by several laboratories world wide, ${ }^{10-13}$ further mutations in the cationic trypsinogen gene have been reported recently. ${ }^{13-15}$ These mutations are also presumed to facilitate the trypsin autodigestion process by altering either the tertiary structure of the protein or the binding of the pancreatic secretory trypsin inhibitor (PSTI).

However, mutations in the cationic trypsinogen gene do not appear to be the whole story. When $14 \mathrm{HP}$ families from different regions of France were scanned for mutations in the cationic trypsinogen gene by denaturing gradient gel electrophoresis (DGGE) analysis, no mutations were detected in either part of the promoter region, in the intron/exon junctions, or in the gene coding sequence of six families. Furthermore, segregation analysis of one family with microsatellite markers (D7S640, D7S495, D7S684, D7S661, D7S676, D7S688) showed that the affected subjects had inherited two different haplotypes. ${ }^{13}$ Locus heterogeneity in HP was also suggested by the negative linkage and absence of the $\mathrm{R} 117 \mathrm{H}$ mutation in two out of eight families studied by Dasouki et al. ${ }^{12}$ These findings, along with the incomplete penetrance of HP, indicated that another gene, or maybe even more than one, is involved in the pathogenesis of HP.

Human PSTI, a single chain polypeptide consisting of 56 amino acids, is also synthesised in the acinar cells of the pancreas. Its main physiological function is believed to be the prevention of the trypsin driven digestive enzyme activation cascade and of pancreatic autodigestion. ${ }^{16}{ }^{17} \mathrm{Be}-$ cause of this central role of PSTI as a negative regulator of trypsin activity, it has been speculated that mutations in this gene may contribute to the development of pancreatitis. ${ }^{13}$ To date, no mutations have been reported in the human PSTI gene, which is located on chromosome $5 .{ }^{17}$ We therefore sought to investigate the possibility of mutations in the PSTI gene in a cohort of hereditary and sporadic chronic pancreatitis patients, as part of a continuing effort to gain further insight into the molecular basis of this disorder.

The human PSTI gene is approximately $7.5 \mathrm{~kb}$ long and is separated into 4 exons. ${ }^{17}$ By designing three exonic primer pairs (sequence not shown), we first successfully amplified the three introns of the PSTI gene from genomic DNA samples. The sizes of them were $\sim 1.7 \mathrm{~kb}, 1.5 \mathrm{~kb}$, and $3.5 \mathrm{~kb}$ respectively, with a total length of $\sim 6.7 \mathrm{~kb}$, which is within the range of $7.5 \mathrm{~kb}$. The three PCR fragments were then cloned into the $\mathrm{pGEM}^{\circledR}$-T vector (Promega) and the inserts partially sequenced using T7 and SP6 promoter primers. Their identity was confirmed by comparing the resulting sequence with the published corresponding exon/ intron boundary sequence. ${ }^{17}$ With the availability of the intronic sequence of $\sim 100 \mathrm{bp}$ immediately flanking each exon, combined with the published sequence of the $5^{\prime}$ regulatory region and the 3 ' untranslated region of the PSTI gene, five DGGE primer pairs were designed to allow for a complete scanning of the $334 \mathrm{bp}$ DNA sequence upstream from the translation start point, as well as of all four exons and corresponding exon/intron junctions of the gene. Detailed information about gel preparation, buffer system, and electrophoresis apparatus for DGGE analysis has been described in our previous paper. ${ }^{18}$ Specifically, the primer sequence, annealing temperature, optimal linear gradient range, and migration time for each amplicon are set out in table 1 . The presence of a DNA variant, which was indicated by an altered pattern in the DGGE analysis, was first confirmed by independent PCR/DGGE analysis. Then a second PCR was performed under the same conditions as for DGGE analysis and the resulting PCR product was cloned and sequenced on an ABI 310. For identifying heterozygous mutations, at least three colonies were sequenced using the T7 and SP6 promoter primers. Each DNA variant has been confirmed by reamplifying and resequencing from both strands in order to avoid artefacts introduced by PCR or sequencing errors.

Among the 14 French HP families we previously studied, the $\mathrm{R} 117 \mathrm{H}$ mutation was detected in four families, a K23R mutation in one family, a N29I in two families, and a -28delTCC in one family. None of these cationic trypsinogen mutations was detected in the remaining six families. ${ }^{13}$ Considering the fact that a certain fraction of HP families do not carry the trypsinogen mutations, and $\sim 20 \%$ of the subjects carrying these mutations are non-symptomatic, we decided to analyse all the 14 families in order to screen for a possible disease causing mutation and also for a possible second mutation which may have an effect on phenotype in the PSTI gene. DGGE analysis and subsequent sequencing showed three DNA variants. They were $-253 \mathrm{~T}>\mathrm{C}$, IVS1-37T $>\mathrm{C}$, and a missense mutation c. $101 \mathrm{~A}>\mathrm{G}$ (resulting in N11S) respectively, named according to the recommendations for a nomenclature system for human gene mutations. ${ }^{19}$ The $-253 \mathrm{~T}>\mathrm{C}$ variant was detected in two families with the $\mathrm{R} 117 \mathrm{H}$ mutation, one family with the K23R mutation, and two families without trypsinogen mutations, both in affected patients and unaffected family members. Also, homozygosity was observed in one patient and one unrelated, disease free subject. Futhermore, this variant was not present in some patients in these families and its frequency evaluated in control chromosomes was $\sim 20 \%$. Thus, the $-253 \mathrm{~T}>\mathrm{C}$ variant is 
clearly a natural polymorphism. The IVS1-37T $>\mathrm{C}$ and c. $101 \mathrm{~A}>\mathrm{G}(\mathrm{N} 11 \mathrm{~S})$ variants occurred together in one family without trypsinogen mutations and were present in the same haplotype. They have been classified as neutral polymorphisms based primarily on the fact that they did not segregate with the disease and that they were present in control chromosomes. Moreover, the IVS1-37T >C variant did not appear to affect the splice recognition sites and the c. $101 \mathrm{~A}>\mathrm{G}$ variant did not replace the asparagine $(\mathrm{N})$ at position 11 of the protein with an amino acid of different physical characteristics, although N11 is conserved in the human and two types of rat PSTI proteins. ${ }^{20}$

Owing to the similar clinical, laboratory, and pathological features of hereditary and sporadic chronic pancreatitis, we also undertook DGGE analysis of sporadic chronic pancreatitis. An additional three heterozygous DNA variants were separately identified in one out of 30 patients with sporadic chronic pancreatitis. The first was a $\mathrm{C}$ to $\mathrm{T}$ transition at position 163 of the PSTI cDNA, resulting in a proline $(\mathrm{P})$ to serine $(\mathrm{S})$ change at position 32 of the protein (c.163C $>\mathrm{T}$ (P32S)). This variant did not change a conserved amino acid and it was present in control chromosomes, indicating a harmless effect on phenotype. The second was a $G$ to $A$ substitution at position 41 upstream from the translation start site $(-41 \mathrm{G}>\mathrm{A})$. This $-41 \mathrm{G}$ is not conserved in the human and the two types of rat PSTI genes and is located $\sim 20 \mathrm{bp}$ downstream from the main transcription start site. This suggests that the $-41 \mathrm{G}>\mathrm{A}$ substitution could not have a significant effect on the transcriptional or translational activity of the PSTI gene. We believe it to be a rare polymorphism as it was not detected in 400 control chromosomes. The third variant was a $\mathrm{C}$ to $\mathrm{T}$ transition at position 174 of the cDNA resulting in a silent mutation at position 35 of the protein (c.174C $>\mathrm{T}(\mathrm{C} 35 \mathrm{C})$ ). In addition, a heterozygous $\mathrm{C}$ to $\mathrm{T}$ substitution at position 22 upstream from the translation start site $(-22 \mathrm{C}>\mathrm{T})$ was detected in two out of 200 control subjects (representing 400 chromosomes). All of the DNA variants detected in this study as well as their frequency evaluated in control chromosomes are described in table 1.

DGGE analysis is one of the most sensitive and efficient established mutation scanning techniques to date. It can allow for the discrimination of DNA molecules differing by as little as only one base change. Using this technique, we identified nearly $100 \%$ of mutations in the cystic fibrosis transmembrane conductance regulator (CFTR) gene in a certain population. ${ }^{21}$ In this study, we detected up to seven different DNA variants. Given this high sensitivity of DGGE analysis, although we cannot exclude the possibility of mutations in the more upstream 5 ' regulatory region or in the remaining intronic sequences, our results strongly suggested that the PSTI gene could be neither a cause nor a cofactor in the development of HP. Future research into this disease may be directed towards other pancreatic digestive proenzyme genes such as the anionic trypsinogen and mesotrypsinogen genes. ${ }^{22}$

When mutations in the cationic trypsinogen gene were identified as the molecular basis of HP, it was questioned whether they could predispose patients to develop sporadic pancreatitis. Until now, these cationic trypsinogen mutations have not been detected in sporadic chronic pancreatitis. ${ }^{1523}$ In this study, although seven different DNA variants in the human PSTI gene were identified in sporadic chronic pancreatitis, none of them seems to have a functional effect on phenotype. Recently, mutations in the CFTR gene have been reported to be closely associated with this disorder ${ }^{24} 25$ and it would be interesting to look at whether CFTR also plays a role in the hereditary form of pancreatitis.

In conclusion, this study is the first comprehensive search for possible mutations in the human PSTI gene that may be linked to pancreatitis, and represents the first identification of seven DNA variants of the gene. Furthermore, PSTI has been excluded from involvement in the pathogenesis of hereditary and sporadic chronic pancreatitis.

We thank Isabelle Quere and Caroline Jacques for help with sequencing, Claudine Verlingue for help with DGGE analysis, and Marjorie Corso for reading the manuscript. This work was supported by the INSERM (CRI No 96-07). JMC is a postdoctoral scientist receiving a grant from the INSERM.

JIAN-MIN CHEN BERNARD MERCIER MARIE-PIERRE AUDREZET CLAUDE FEREC

Centre de Biogenetique, University, Hospital, ETSBO, 46 rue Felix Le

Dantec, BP454, 29275 Brest Cedex, France

Correspondence to: Dr Ferec, Claude.Ferec@univ-brest.fr

1 Perrault J. Hereditary pancreatitis. Gastroenterol Clin North Am 1994;23:74352.

2 Chiara $\mathrm{H}$. Ueber selbstverdauung des menschlichen pankreas. Zeitschr Heilkd 1896;17:69-96.

3 Comfort MW, Steinberg AG. Pedigree of a family with hereditary chronic relapsing pancreatitis. Gastroenterology 1952;21:54-63.

4 Le Bodic L, Bignon JD, Raguenes O, et al. The hereditary pancreatitis gene maps to long arm of chromosome 7. Hum Mol Genet 1996;5:549-54.

5 Whitcomb DC, Preston RA, Aston CE, et al. A gene for hereditary pancreatitis maps to chromosome 7q35. Gastroenterology 1996;110:1975-80.

6 Pandya A, Blanton SH, Landa B, et al. Linkage studies in a large kindred

with hereditary pancreatitis confirms mapping of the gene to a $18-\mathrm{cM}$ with hereditary pancreatitis confirms map
region on 7 q. Genomics $1996 ; 38: 227-30$.

7 Whitcomb DC, Gorry MC, Preston RA, et al. Hereditary pancreatitis is caused by a mutation in the cationic trypsinogen gene. Nat Genet 1996;14: 141-5

8 Varallyay E, Pal G, Patthy A, Szilagyi L, Graf L. Two mutations in rat trypsin confer resistance against autolysis. Biochem Biophys Res Commun 1998;243: 56-60

$9 \mathrm{Li} \mathrm{XF}$, Nie X, Tang JG. Anti-autolysis of trypsin by modification of autolytic site Arg1 17. Biochem Biophys Res Commun 1998;250:235-9.

10 Gress TM, Micha AE, Lacher U, Alder G. Diagnosis of a "hereditary pancreatitis" by the detection of a mutation in the cationic trypsinogen gene. Dtsch Med Wochenschr 1998;123:453-6.

11 Bell SM, Bennett C, Markham AF, Lench NJ. Evidence for a common mutation in hereditary pancreatitis. Mol Pathol 1998;51:115-17.

12 Dasouki MJ, Cogan J, Summar ML, et al. Heterogeneity in hereditary pancreatitis. Am F Med Genet 1998;77:47-53.

13 Ferec C, Raguenes O, Salomon R, et al. Mutations in the cationic trypsinogen gene and evidence for genetic heterogeneity in hereditary pancreatitis.
f Med Genet 1999;36:228-32.

14 Gorry MC, Gabbaizedeh D, Furey W, et al. Mutations in the cationic trypsinogen gene are associated with recurrent acute and chronic pancreatrypsinogen gene are associated with recu
titis. Gastroenterology 1997;113:1063-8.

15 Teich N, Mossner J, Keim V. Mutations of the cationic trypsinogen in hereditary pancreatitis. Hum Mutat 1998;12:39-43.

16 Laskowski MJ, Ikunoshin K. Protein inhibitors of proteinases. Anпu Rev Biochem 1980;49:593-626.

17 Horii A, Kobayashi T, Tomita N, et al. Primary structure of human pancreatic secretory trypsin inhibitor (PSTI) gene. Biochem Biophys Res Commun 1987;149:635-41.

18 Macek M, Mercier B, Mackova A, et al. Sensitivity of the denaturing gradient gel electrophoresis technique in detection of known mutations and novel Asian mutations in the CFTR gene. Hum Mutat 1997;9:136-47.

19 Antonarakis SE, the Nomenclature Working Group. Recommendations for a nomenclature system for human gene mutations. Hum Mutat 1998;11:1-3.

20 Horii A, Tomita N, Yokouchi H, et al. On the cDNAs for two types of rat pancreatic secretory trypsin inhibitor. Biochem Biophys Res Commun 1989; 162:151-9.

21 Ferec C, Audrezet MP, Mercier B, et al. Detection of over $98 \%$ cystic fibrosis mutations in a Celtic population. Nat Genet 1992;1:188-91.

22 Nyaruhucha CNM, Kito M, Fukuoka SI. Identification and expression of Nyaruhucha CNM, Kito M, Fukuoka SI. Identification and expression of
the cDNA-encoding human mesotrypsin(ogen), an isoform of trypsin with inhibitor resistance. F Biol Chem 1997;272:10573-8.

23 Rossi L, Whitcomb DC, Ehrlich GD, et al. Lack of R117H mutation in the cationic trypsinogen gene in patients with tropical pancreatitis from Bangladesh. Pancreas 1998;17:278-80.

24 Cohn JA, Friedman KJ, Noone PG, Knowles MR, Silverman LM, Jowell PS. Relation between mutations of the cystic fibrosis gene and idiopathic pancreatitis. N Engl f Med 1998;339:653-8.

25 Sharer N, Schwarz M, Malone G, et al. Mutations of the cystic fibrosis gene in patients with chronic pancreatitis. $N$ Engl f Med 1998;339:645-52. 


\section{A case of inv dup(8p) with early onset breast cancer}

EDITOR-More than 50 cases have been described with inv $\operatorname{dup}(8 \mathrm{p})$ which can be either di- or monocentric. ${ }^{1-4} \mathrm{~A}$ rough estimate of the prevalence of both is $1 / 22000-30000$ of the white population. Concurrently with the $8 \mathrm{p}$ duplication, markers at the tip of chromosome 8 are consistently deleted. All the cases described are associated with mental retardation, facial dysmorphism, brain defects and/or developmental delay. Allele loss and amplifications of regions of chromosome $8 \mathrm{p}$ are commonly reported in sporadic breast cancer, ${ }^{5-7}$ and two recent papers have suggested linkage to $8 p 11-12$ in familial breast cancer..$^{5-8}$ We report a case of $8 p$ duplication and inversion in a woman who developed breast cancer at the age of 36 , with a personal history of developmental abnormality and a family history of breast and other cancers. Because of the possible link between this chromosomal abnormality and a breast cancer predisposing gene on chromosome $8 \mathrm{p}$, we analysed the chromosome in more detail. Our analysis suggests, however, that the cancers and the chromosomal abnormality are unrelated.

The patient (DD003-1EW) was born in 1951. She was considered to have had a birth injury resulting in hypoxic

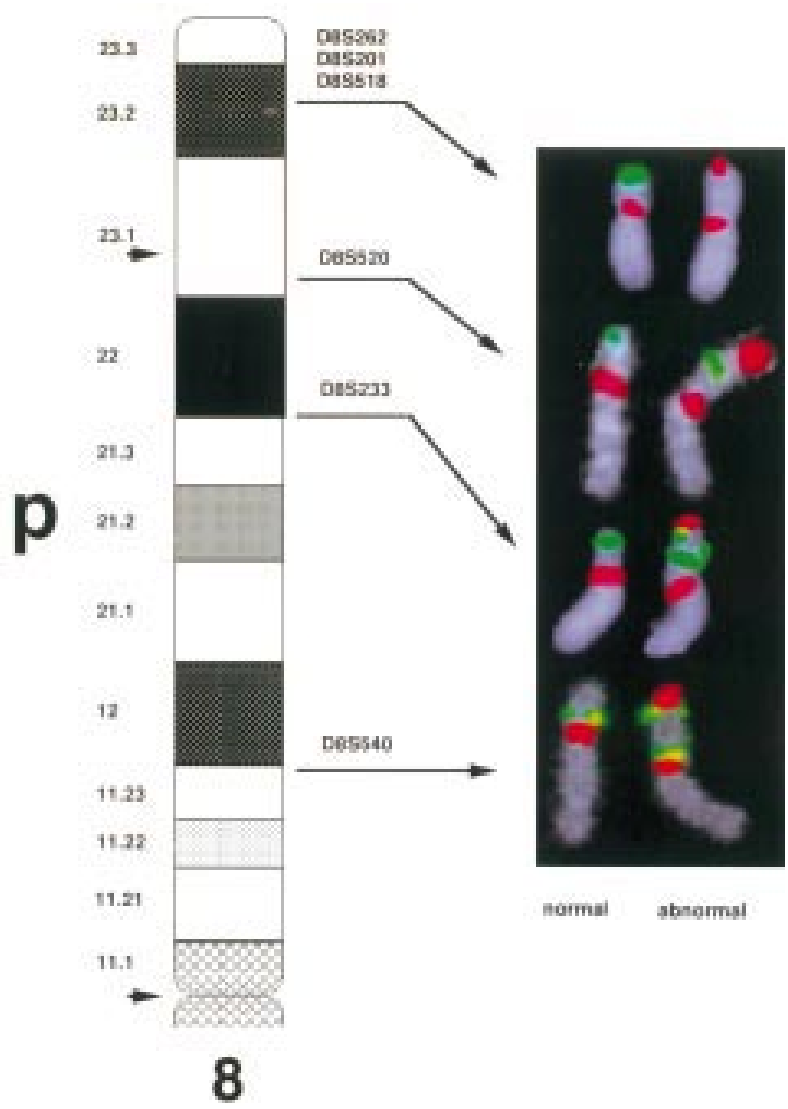

Figure 1 FISH analysis of different $8 p$ YAC probes (green) in combination with a human chromosome 8 specific centromeric probe (red). (Yellow colour indicates overlap of the signals). (Left) Ideogram of $8 p$ which shows the localisation of the probes. The duplicated and inverted portion of the rearranged chromosome $8 p$ is indicated by arrowheads. (Right) Images obtained for the normal and rearranged chromosome 8 showing inv dup $(8 p)$. The following YAC probes were used from top to bottom: Y787_c_11,Y700_d_3,Y812_g_7,Y936_g_4. encephalopathy and cerebral palsy. At the age of 25 she had a left breast biopsy which was diagnosed as benign, and at the age of 36 (in 1987) she had an infiltrating ductal carcinoma of the right breast. In 1988 chromosome analysis was undertaken by $G$ banding because of a suspected "developmental disorder of the brain". This showed an inversion and duplication of chromosome 8p. In her family, her mother is well, her maternal grandfather was reported to have had colon cancer, his sister (the patient's great aunt) to have had breast and colon cancers and his mother breast and pancreatic cancer, a son and grandson of the great aunt to have had leukaemia of unspecified type, and a granddaughter to have had breast cancer in her 30s. None of these family members could, however, be contacted.

An $8 \mathrm{p}+$ karyotype was reported suggesting an inv $\operatorname{dup}(8 \mathrm{p})(\mathrm{p} 11.2 \rightarrow \mathrm{p} 23.1)$ after routine $\mathrm{G}$ banding chromosome analysis. Metaphase chromosomes from EBV immortalised lymphoblasts from the patient were prepared after synchronisation with thymidine and incubation with colcemid by standard techniques. Fluorescence in situ hybridisation (FISH) studies performed with a whole chromosome 8 paint (Cambio) showed that the additional material present in the short arm of the rearranged chromosome 8 is derived from chromosome 8 (data not shown). To define the breakpoints of the rearrangement more accurately, dual colour FISH experiments were performed using total yeast DNA from YAC clones from chromosome 8 (HGMP Resource Centre, UK) together with a chromosome 8 specific centromeric probe (Boehringer Mannheim). By analysis of 20 metaphases each it could be shown that the short arm of the rearranged chromosome $8 \mathrm{p}$ is dicentric with most of the short arm duplicated (cen $\rightarrow$ p23.1) and inverted (fig 1). The telomeric region distal to p23.1 is deleted. The proximal breakpoint seems to be the centromere as the dicentric chromosome 8 shows a second centromere at the very end of the tip of the short arm.

Neither the breakpoints nor the telomeric deletion lay in regions associated with breast carcinomas, which frequently show allelic deletions in regions 8p11-p12 and 8 p21-p22 in sporadic cases. ${ }^{56} 8 \mathrm{p} 12$ is also found to be amplified in $10-15 \%$ of breast tumours. ${ }^{7}$ For the NEFL marker (8p11-p12), a lod score of 2.5 was obtained by linkage analysis using families unlinked to $B R C A 1$ or $B R C A 2$ indicating the presence of a putative $B R C A 3$ gene. ${ }^{5}$ Because samples from other family members of the index case were not available for linkage analysis, mutational analysis of $B R C A 1$ and $B R C A 2$ was performed in the proband but did not detect any mutation (data not shown).

In conclusion, the presented case of inv $\operatorname{dup}(8 \mathrm{p})$ shows the genotype of other reported cases associated with developmental delay and/or mental retardation. The occurrence of breast cancer is probably coincidental and unrelated to the chromosome $8 \mathrm{p}$ rearrangement.

We thank Ian Roberts for providing help with the image analysis system. This work was supported by grant D/96/03248 to MS from the Deutsche Krebshilfe.

M SELTMANN

P HARRINGTON

B A J PONDER

CRC Human Cancer Genetics Research Group, Box 139, Cambridge Institute for Medical Research, Cambridge CB2 2XY, UK

L R WILLATT

Cytogenetics Laboratory, Box 108, Level 2, Addenbrooke's Hospital, Hills Road, Cambridge, CB2 2QQ, UK

A C HEPPELL-PARTON Medical Research Council, Hills Road, Cambridge, CB2 2QQ, UK 
University of California, Irvine, USA

H ANTON-CULVER

Correspondence to: Dr Seltmann, Essen University Medical School, Virchow Strasse 173, Institute of Cell Biology, D-45147 Essen, Germany

1 Florida G, Piantanida M, Minelli A, et al. The same molecular mechanism at the maternal meiosis I produces mono- and dicentric $8 \mathrm{p}$ duplications. Am f Hum Genet 1996;58:785-96.

2 Guo WJ, Faith CD, Zapata MC, Miller ME. Clinical and cytogenetic findings in seven cases of inverted duplication of $8 \mathrm{p}$ with evidence of a telomeric deletion using fluorescence in situ hybridization. Am f Med Genet 1995;58:230-6.

3 Feldman GL, Weiss L, Phelan MC, Schroer RJ, Van Dyke DL. Inverted duplication of 8p: ten new patients and review of the literature. $A m \mathcal{F} \mathrm{Med}$ Genet 1993;47:482-6.
4 Minelli A, Floridia G, Rossi E, et al. D8S7 is consistently deleted in inverted duplications of the short arm of chromosome 8 (inv dup 8p). Hum Genet 1993;92:391-6.

5 Kerangueven F, Essioux L, Dib A, et al. Loss of heterozygosity and linkage analysis in breast carcinoma: indication for a putative third susceptibility gene on the short arm of chromosome 8. Oncogene 1995;10: 1023-6.

6 Chuaqui RF, Sanz-Ortega J, Vocke C, et al. Loss of heterozygosity on the short arm of chromosome 8 in male breast carcinomas. Cancer Res short arm of

7 Dib A, Adelaide J, Chaffanet M, et al. Characterization of the region of the short arm of chromosome 8 amplified in breast carcinoma. Oncogene 1995; 10:995-1001.

8 Chaffanet M, Popovici C. $t(6 ; 8)$ and $t(8 ; 13)$ translocations associated with stem cell myeloproliferative disorders have close or identical breakpoints in chromosome region 8p11-12. Oncogene 1998;16:945-9.

\section{Appendiceal carcinoma complicating adenomatous polyposis in a young woman with a de novo constitutional reciprocal translocation $\mathrm{t}(5 ; 8)(\mathrm{q} 22 ; \mathrm{p} 23.1)$}

EDITOR-Familial adenomatous polyposis (FAP) is an autosomal dominant condition characterised by the presence of more than 100 adenomatous polyps in the colon and rectum. Polyps generally first appear in the second or third decade of life and are usually most numerous distally. Left untreated, colorectal cancer is virtually inevitable and generally arises in the fourth or fifth decade. ${ }^{1}$ Adenocarcinoma of the appendix is an uncommon neoplasm and has only rarely been reported in association with FAP. ${ }^{2}$

The gene responsible for FAP, $A P C$, was initially localised to the long arm of chromosome five (5q) by linkage. ${ }^{34}$ This followed a case report describing carcinomas of the rectum and ascending colon, adenomatous polyposis, mental retardation, and various dysmorphic fea- tures in a 42 year old man with a constitutional deletion of 5q. ${ }^{5}$ Most patients with FAP have normal karyotypes. ${ }^{6}$ Mental retardation and dysmorphic features are unusual in such people but characterise those rare patients with cytogenetically visible $5 \mathrm{q}$ deletions and FAP. ${ }^{5-12}$ The few reports detailing the clinical findings in patients with submicroscopic deletions of $A P C$ suggest that such people may be mentally normal. ${ }^{13} 14$

In this report we describe a patient with adenomatous polyposis, mental retardation, and an apparently balanced translocation $\mathrm{t}(5 ; 8)(\mathrm{q} 22 ; \mathrm{p} 23.1)$ causing submicroscopic deletion of $A P C$ and $M C C$.

Clinical data were obtained by review of medical records. In addition, the patient was interviewed and examined by two of the authors (JF and AS) before her death. Cytogenetic studies were performed using standard techniques on a 72 hour peripheral blood culture with GTG banding, as previously reported. ${ }^{6}$

Slides for fluorescence in situ hybridisation (FISH) were obtained using the cell suspension retained after routine cytogenetic harvest. RNAse treatment, probe and chromosomal denaturation, and hybridisation conditions were as previously described ${ }^{15}$ with the stringencies adjusted after assessment of the optimal conditions for each probe combination. The biotinylated probes were detected with
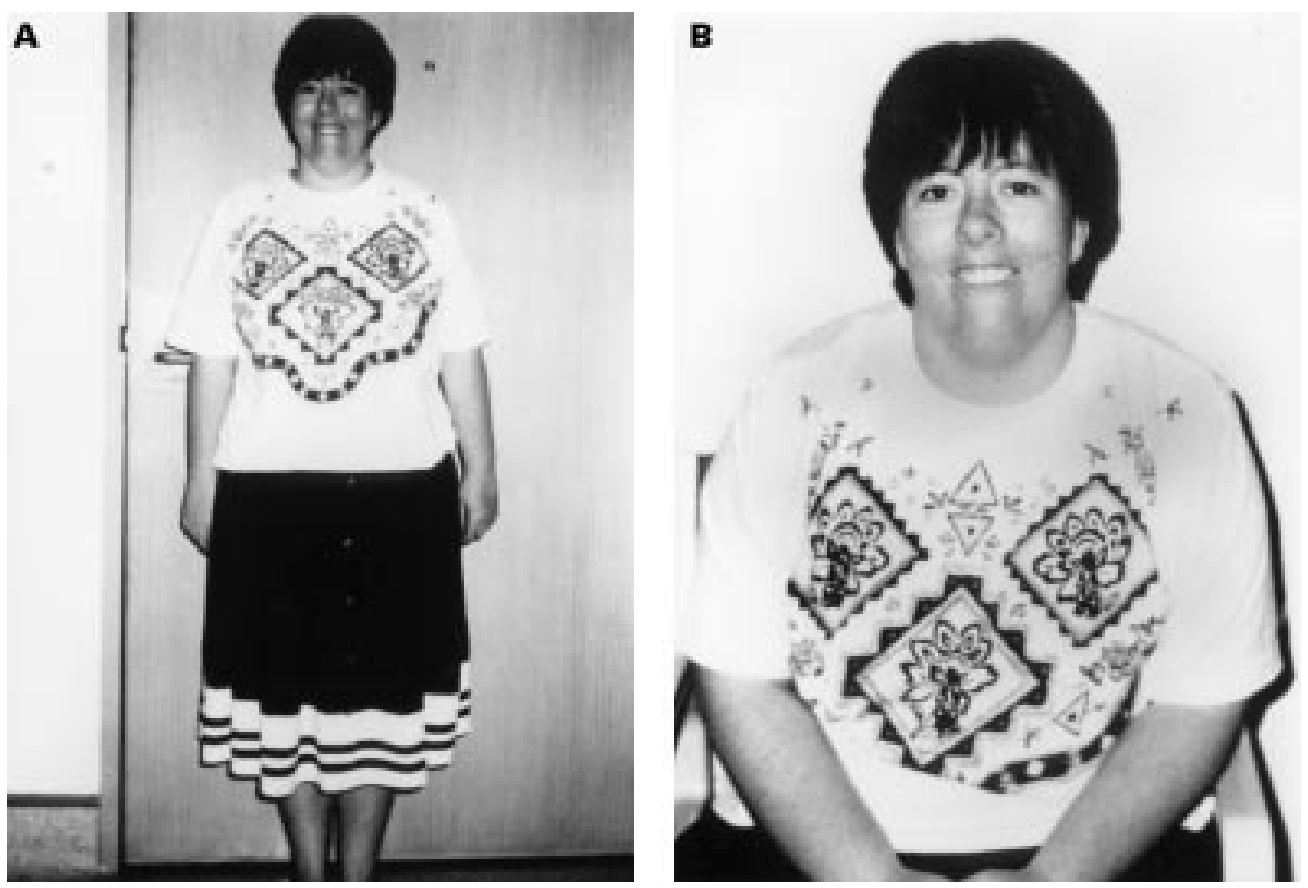

Figure $1(A, B)$ The patient aged 26 years. 
avidin-FITC (Calbiochem) followed by biotinylated antiavidin (Vector) and finally avidin-FITC. The digoxigenin labelled probes were detected with mouse anti-digoxigenin followed by sheep anti-mouse Ig-rhodamine conjugated antibody (Boehringer Mannheim). Chromosomes, counterstained with DAPI (Sigma) and visualised by fluorescence microscopy (Zeiss), were captured using a computer image analysis system (Cytovision).

The following probes were used in FISH studies: MCC 40CI (partial MCC cDNA nucleotides 1634-3969), FB70B (partial $A P C$ cDNA nucleotides 2877-6452), and APC (full length $A P C$ cDNA) each kindly provided by Dr Bert Vogelstein (Johns Hopkins Oncology Center, Baltimore); D5S23 (chromosome 5p probe, Vysis); EGR-1 (chromosome 5q31 probe, Vysis); CHR8B/wcp8 (chromosome 8 library probe, Cambio); D8Z1 (chromosome 8 centromere probe, Oncor).

Genomic DNA was extracted from blood samples using the Instagene purification matrix (Biorad) according to the manufacturer's instructions. Each polymerase chain reaction (PCR) used 50-100 ng genomic DNA, $50 \mathrm{pmol} / 1$ of each oligonucleotide primer, $0.2 \mathrm{mmol} / 1$ of each $\mathrm{dNTP}$ (Pharmacia), 1.25 U Amplitaq DNA polymerase (Perkin Elmer) in Amplitaq reaction buffer $(10 \mathrm{mmol} / \mathrm{l}$ Tris- $\mathrm{HCl}$, $50 \mathrm{mmol} / 1 \mathrm{KCl}, \mathrm{MgCl}$ optimised for each primer pair, $\mathrm{pH}$ 8.3) to a final volume of $25 \mu$. Thirty five amplification cycles were performed using an FTS-320 Thermal Sequencer (Corbett Research).

An $R s a \mathrm{I}$ polymorphism in exon 11 of $A P C^{16}$ was analysed by amplification of exon 11 and digestion of the PCR product with RsaI (Boehringer). Reaction products were separated by electrophoresis in a $10 \%$ non-denaturing polyacrylamide minigel (Biorad) and visualised by ethidium bromide staining. The $255 \mathrm{bp}$ amplification product yielded digestion fragments of $155 \mathrm{bp}$ and $100 \mathrm{bp}$. A CA repeat polymorphism within $M C C(\mathrm{CAMBC})^{17}$ and a CA repeat polymorphism between $A P C$ and $M C C$ $(\mathrm{LNS}-\mathrm{CA})^{13}{ }^{18}$ were labelled by $\left[\alpha \mathrm{S}^{35}\right] \mathrm{dATP}$ incorporation during PCR and characterised by electrophoresis in a $6 \%$ denaturing polyacrylamide gel and autoradiography as previously reported. ${ }^{19}$

The patient (fig 1) was the second child of a 32 year old mother and a 33 year old father. Her older brother was well and mentally normal. She was born prematurely at 29 weeks' gestation after an uncomplicated pregnancy. There were no major problems in the neonatal period but she was slow to speak and did not walk until the age of 2 years. At that time she began to have generalised convulsions. These were only partially controlled by medication and continued until the age of 18 . Her performance at school was poor. Her hospital file notes an estimated IQ between 70 and 80 at the age of 10 although the method of assessment was not recorded. Physical examination at this time showed crowded dentition and she later required extensive dental work. The posterior hairline was noted to be low. The head circumference was normal ( 75 th centile) while height was on the 10th centile. The third and fourth toes were short with the fifth toe longer than the fourth. Bilateral genu recurvatum was evident and the patient was mildly ataxic. There were no skin lesions and the fundi were normal.

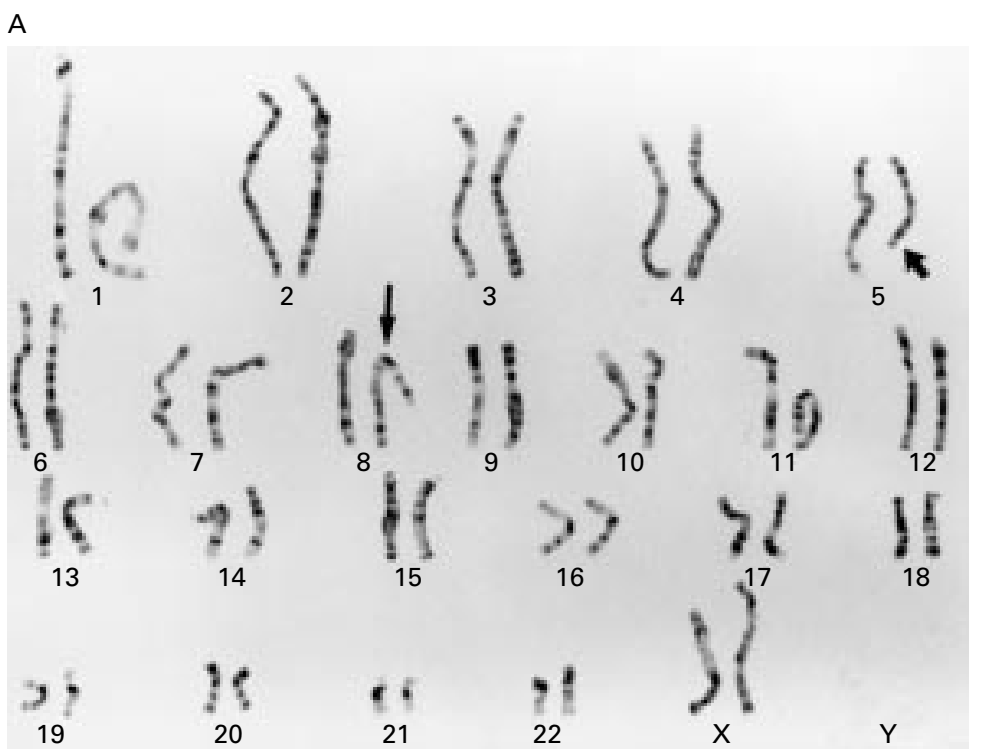

B
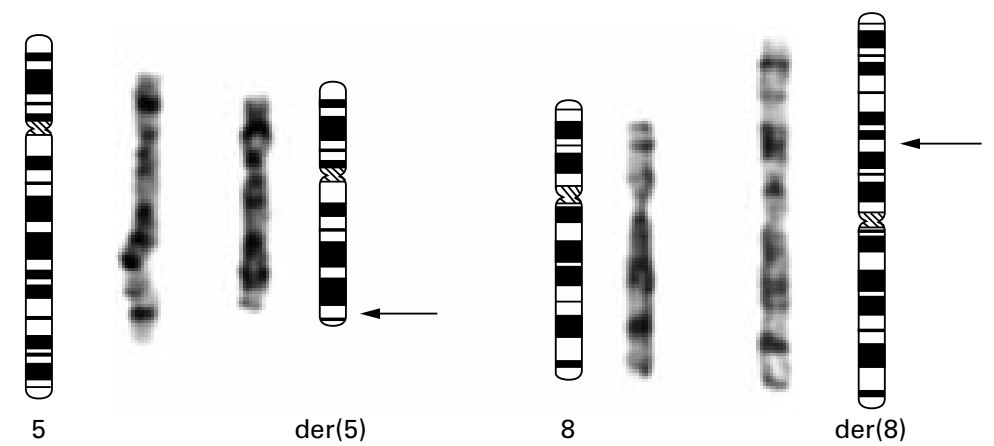

Figure 2 (A) GTG banded karyotype showing the translocation $t(5 ; 8)(q 22 ; p 23.1)$ in the patient. The arrows indicate the sites of the breakpoints. (B) Normal and derivative chromosomes 5 and 8. 


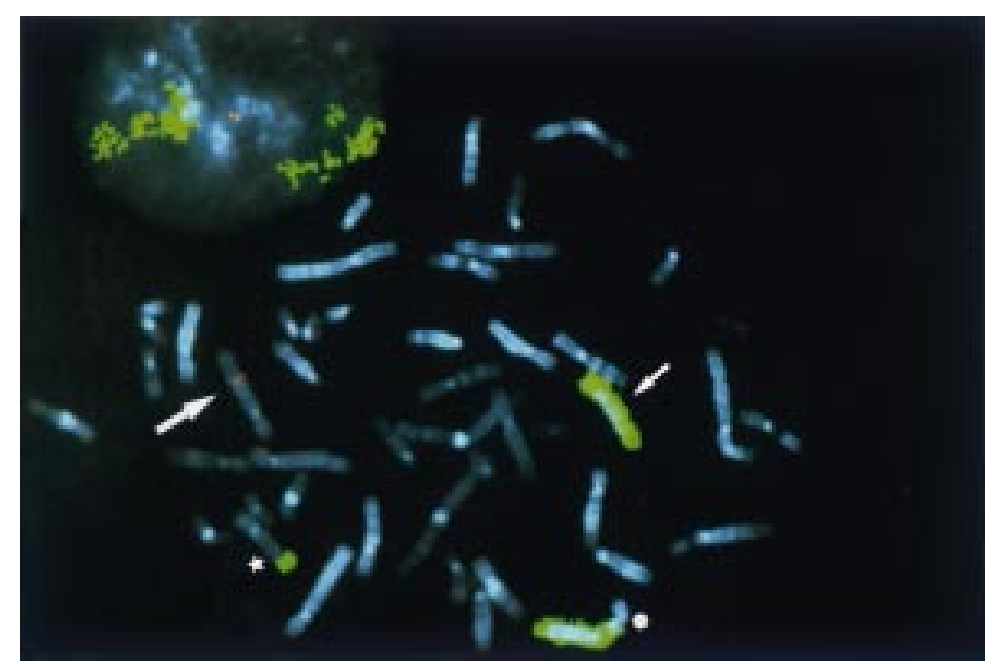

Figure 3 FISH study using the chromosome 8 library probe, CHR8B/wcp8, labelled green and the MCC gene probe, MCC 40CI, labelled red. An MCC signal is seen only on the normal chromosome 5 (large arrow) and not on either the der(8) (asterisk) or the der(5) (star) chromosomes. The normal chromosome 8 is indicated by a small arrow.

Visual acuity and hearing were unimpaired. An EEG at the age of 4 was abnormal with excessive generalised slow wave activity. A cerebral CT scan at 9 years showed mild ventricular dilatation and localised atrophy in the frontal areas and bordering the interhemispheric commissure. She attended a special school until the age of 17 and was actively involved in sports. Subsequently she worked successfully in a sheltered workshop while living independently with a group of mildly handicapped people.

She presented acutely at 26 years of age with a 24 hour history of right iliac fossa pain. She was febrile and had guarding and rebound tenderness at the site of her pain. A diagnosis of acute appendicitis was made and an appendicectomy performed. The appendix contained a mucin secreting carcinoma arising in a dysplastic villous adenoma and invading through the full thickness of the muscle wall. A right hemicolectomy was performed. The appendiceal stump had foci of adenomatous change but there was no residual carcinoma. Numerous small adenomatous polyps were noted throughout the right colon but the exact number was not recorded. Sigmoidoscopy subsequently showed left sided polyps but these were less numerous than had been found proximally. Eight months after hemicolectomy she presented again with a painful right iliac fossa mass. Laparotomy confirmed local tumour recurrence which could be only partially excised. She was treated with 5-fluorouracil and folinic acid but died approximately 12 months later. A post mortem examination was not performed.

Cytogenetic analysis showed a female karyotype with a translocation involving chromosomes 5 and 8 at breakpoints $\mathrm{q} 22$ and p23.1 respectively (fig 2 ). The translocation was cytogenetically balanced. Both parents had normal karyotypes. The patient's brother refused testing.

FISH studies were performed using several probe combinations: APC, D5S23, and EGR-1; FB70B and D5S23; FB70B and D8Z1; MCC 40CI and CHR8B/wcp8 (fig 3); and MCC $40 \mathrm{CI}$ and D8Z1. These studies confirmed the translocation and showed submicroscopic deletion of both $A P C$ and $M C C$. The $A P C$ and $M C C$ probes hybridised only to the normal chromosome 5 and not to the der(5) or der(8) chromosomes.

To confirm that the translocation identified had resulted in deletion of the $A P C$ and $M C C$ genes, intragenic polymorphisms were examined in DNA from the patient and her parents. The RsaI polymorphism in exon 11 of $A P C$ was informative in the family. The patient's mother was homozygous for absence of the restriction site whereas her father was homozygous for presence of the restriction site. The patient had only a maternally derived allele, sug-

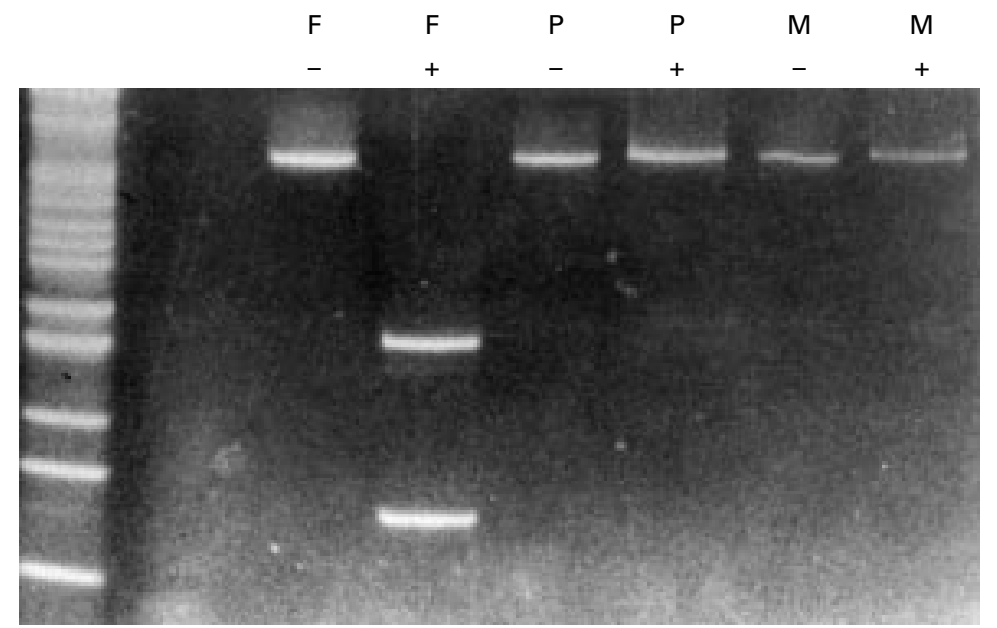

Figure 4 Exon 11 of APC was amplified from the patient $(P)$, her father $(F)$, and her mother $(M)$. The PCR product from each source was electrophoresed in a 10\% polyacrylamide gel either with (+) or without (-) preceding digestion with RsaI. The first lane shows a molecular weight marker (MspI digest of $p B R 322)$. 


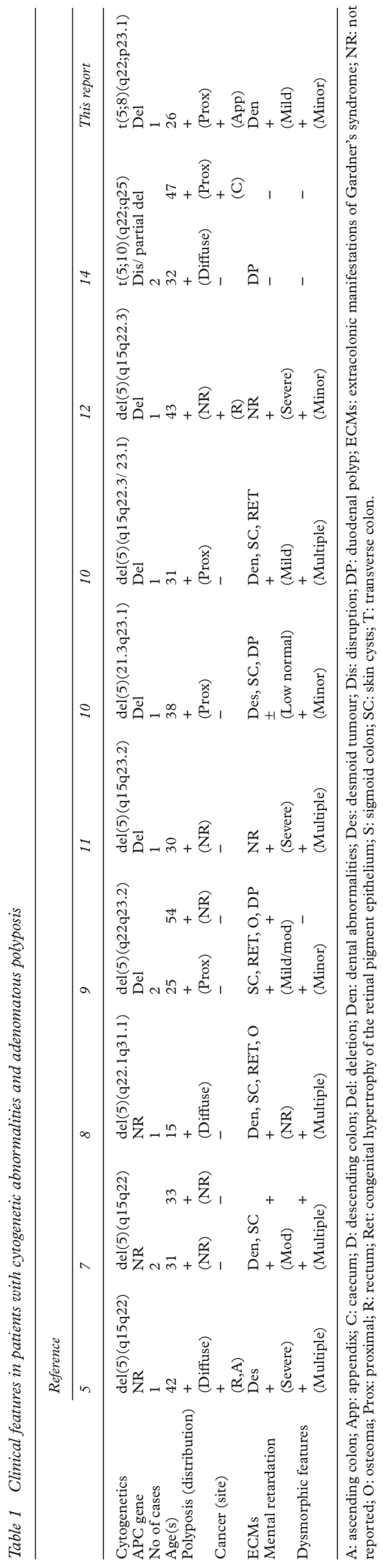

gesting that she was hemizygous for this region of $A P C$ and that the translocation had involved the paternally derived chromosome (fig 4). The MCC CA repeat polymorphism was not informative in this family but the patient amplified only one allele consistent with hemizygosity for MCC. Both parents also shared this allele. Analysis of LNSCA, between $A P C$ and $M C C$, was informative in the family. Again, the patient had inherited a maternal but not a paternal allele. Seven microsatellite polymorphisms from other chromosomes were examined in the three family members. The results did not suggest non-paternity.

There have been 10 previously described cases in eight families of cytogenetically visible deletions encompassing 5 q22 in association with adenomatous polyposis of the colon and rectum. ${ }^{5-12}$ Varying degrees of mental retardation and a range of dysmorphic features have been described in these patients (table 1). Others have reported patients with similar deletions, mental retardation, and congenital anomalies in whom colonic disease was either not sought or had not yet developed. ${ }^{112021}$ Submicroscopic deletion of $A P C$ has been described in mentally normal subjects without dysmorphic features. ${ }^{13}$ In the current report, a submicroscopic deletion encompassing $A P C$ and $M C C$ has produced adenomatous polyposis in association with mild retardation and minor dysmorphic features. The mental retardation observed in this case may relate to the greater extent of the submicroscopic deletion. In our patient an area encompassing both $A P C$ and $M C C$ was deleted and it is likely that other neighbouring genes have been either deleted or disrupted. In the family described by Mandl et $a l,{ }^{13}$ the deletion spanned a smaller region including the $A P C$ gene from exon 11 to the 3 ' untranslated region and the adjacent $D P 1$ gene. $M C C$ was not involved.

We are aware of only one other report of FAP resulting from a chromosome 5 translocation. ${ }^{14}$ In that report an affected mother and daughter are described with colonic polyposis and a translocation $\mathrm{t}(5 ; 10)(\mathrm{q} 22 ; \mathrm{q} 25)$ resulting in disruption of the $A P C$ gene and an intragenic deletion. Neither mental retardation nor dysmorphic features were reported in these two patients.

In the current report, FAP was discovered after the patient presented with acute appendicitis. An appendiceal carcinoma was identified in the resection specimen. Appendiceal carcinoma has occasionally been described in patients with FAP but there is only one other published case of FAP first presenting as acute appendicitis with appendiceal carcinoma. Molecular genetic data were not reported in that case. ${ }^{2}$ In the current report, appendiceal carcinoma has developed in association with a submicroscopic deletion of $A P C$ and $M C C$ and polyps were most numerous in the right hemicolon. Similarly, in the report of van der Luijt et $a l^{14}$ of a $5 \mathrm{q}$ translocation and polyposis, polyps were noted to be more numerous in the proximal colon of the mother and a caecal adenocarcinoma was found in her resection specimen. The reported distribution of colorectal polyps and carcinomas in patients with cytogenetically visible deletions of $A P C$ has been similar and more typical of attenuated adenomatous polyposis coli (AAPC) than of classical FAP. In AAPC, polyps generally develop later and tend to be more dense proximally than distally. ${ }^{22}$ The reverse is true of classical FAP. ${ }^{1}$ AAPC has been attributed in some cases to constitutional mutations at the $5^{\prime}$ end of $A P C$ while in others mutations in exon 9 or at the $3^{\prime}$ end of the gene have been reported..$^{22-25}$ It has been suggested that the $5^{\prime}$ mutations result in very short protein products that, either through rapid degradation or lack of the necessary oligomerisation domains, do not compete with the residual wild type $A P C$ or bind to it, producing a dominant negative effect. ${ }^{14}{ }^{23-25}$ Mutations at the $3^{\prime}$ end of $A P C$ may also produce null alleles although the explanation for this 
remains unclear. ${ }^{24}$ Deletions of $A P C$ produce a true null allele. In this respect they may be functionally comparable to the 5' and 3' APC mutations in AAPC and this may explain some of the phenotypic similarities noted above.

The contribution of MCC deletion to colorectal carcinogenesis in the current case remains unclear. Constitutional deletion of $A P C$ is presumably sufficient to explain the adenomatous polyposis in this patient and there are no reported cases of constitutional MCC mutation or deletion alone producing human colorectal disease. Somatic mutation of $M C C$ has been reported in colorectal cancers but the role of $M C C$ as an independent colorectal tumour suppressor gene has subsequently been questioned. ${ }^{26}{ }^{27}$

We thank the patient and her parents for their cooperation, the patient's surgeon, Dr John Neophyton, and general practitioner, Dr John Cameron, for providing clinical details, Dr Dorothy Painter for reviewing the histopathology, Cathy Abbott for assistance in preparing DNA probes, and Nicole Chia for assistance in the cytogenetic studies.

D KOOREY

N J BASHA C TOMARAS

Departments of Gastroenterology and Molecular Genetics, Royal Prince Alfred Hospital, Sydney, Australia

J FREIMAN

Department of Medicine, Sutherland Hospital, Sydney, Australia

L ROBSON

Department of Clinical Cytogenetics, The New Children's Hospital, A SMITH

Sydney, Australia

Correspondence to: Dr Koorey, A W Morrow Gastroenterology and Liver Centre, Royal Prince Alfred Hospital, Missenden Road, Camperdown, Sydney 2121, Australia

1 Bussey H. Familial polyposis coli. Baltimore: The Johns Hopkins University Press, 1975

2 Parker G, Stollman N, Rogers A. Adenomatous polyposis coli presenting as adenocarcinoma of the appendix. Am f Gastroenterol 1996;91:801-2.

Bodmer W, Bailey C, Bodmer J, et al. Localisation of the gene for familial adenomatous polyposis on chromosome 5. Nature 1987;328:614-16.

4 Leppert M, Dobbs M, Scambler P, et al. The gene for familial polyposis coli maps to the long arm of chromosome 5. Science 1987;238:1411-13.

5 Herrera L, Kakati S, Gibas L, Pietrzak E, Sandberg A. Gardner syndrome in a man with an interstitial deletion of 5q. Am f Med Genet 1986;25:473-6.

6 Koorey D, Smith A. Normal high resolution karyotypes in 26 unrelated individuals with hereditary colorectal neoplasia. Am $\mathcal{F}$ Gastroenterol 1992;87:1736-9.

7 Hockey K, Mulcahy M, Montgomery P, Levitt S. Deletion of chromosome 5q and familial adenomatous polyposis. F Med Genet 1989;26:61-2.
8 Kobayashi T, Narahara K, Yokoyama Y, et al. Gardner syndrome in a boy with interstitial deletion of the long arm of chromosome 5. Am F Med Genet 1991;41:460-3.

9 Cross I, Delhanty J, Chapman P, et al. An intrachromosomal deletion and familial adenomatous polyposis coli in two generations. F Med Genet 1992; 29:175-9.

10 Hodgson S, Coonar A, Hanson P, et al. Two cases of 5q deletions in patients with familial adenomatous polyposis: possible link with Caroli's disease. $\mathcal{F}$ Med Genet 1992;30:369-75.

11 Lindgren V, Bryke C, Ozcelik T, Yang-Feng T, Francke U. Phenotypic, cytogenetic, and molecular studies of three patients with constitutional deletions of chromosome 5 in the region of the gene for familial adenomatous polyposis. Am f Hum Genet 1992;50:988-97.

12 Barber J, Ellis K, Bowles L, et al. Adenomatous polyposis coli and a cytogenetic deletion of chromosome 5 resulting from a maternal intrachromosomal insertion. 7 Med Genet 1994;31:312-16.

13 Mandl M, Caspari R, Jauch A, et al. Familial adenomatous polyposis: a submicroscopic deletion at the APC locus in a family with mentally normal patients. Hum Genet 1996;97:204-8.

14 Van der Luijt R, Tops C, Meera Khan P, et al. Molecular, cytogenetic, and phenotypic studies of a constitutional reciprocal translocation $\mathrm{t}(5 ; 10)(\mathrm{q} 22$; q25) responsible for familial adenomatous polyposis in a Dutch pedigree. Genes Chrom Cancer 1995;13:192-202.

15 James C, Jauch A, Robson L, Watson N, Smith A. A 31/2 year old girl with trisomy 19q defined by FISH. 7 Med Genet 1996;33:795-7.

16 Kraus C, Ballhausen W. Two intragenic polymorphisms of the APC-gene detected by PCR and enzymatic digestion. Hum Genet 1992;88:705-6.

17 Van Leeuwen C, Tops C, Breukel C, et al. CA repeat polymorphism within the MCC (mutated in colorectal cancer) gene. Nucleic Acids Res 1991;19:5805.

18 Spirio L, Joslyn G, Nelson L, Leppert M, White R. A CA repeat 30-70 kb downstream from the adenomatous polyposis coli (APC) gene. Nucleic Acids Res 1991;19:6348.

19 Koorey D, McCaughan G, Trent R, Gallagher N. Dinucleotide repeat polymorphism at the D5S134 locus linked to the adenomatous polyposis coli (APC) gene. Hum Mol Genet 1992;1:655.

20 Pescia G, Gaide A, Juillard E. Syndrome dysmorphique, débilité mentale et délétion interstitielle des bras longs d'un chromosome 5. Ann Genet 1978; 21:161-3.

21 Silengo M, Luzzatti L, Centerwall W, Costello J, Parslow M. Interstitial deletion of the long arm of chromosome no 5 in two unrelated children with congenital anomalies and mental retardation. Clin Genet 1981;19:17480 .

22 Lynch H, Smyrk T, McGinn T, et al. Attenuated familial adenomatous polyposis (AFAP). Cancer 1995; 76:2427-33.

23 Spirio L, Olschwang S, Groden J, et al. Alleles of the APC gene: an attenuated form of familial polyposis. Cell 1993;75:951-7.

24 Van der Luijt R, Meera Khan P, Vasen H, et al. Germline mutations in the 3 part of APC exon 15 do not result in truncated proteins and are associated with attenuated adenomatous polyposis coli. Hum Genet 1996;98:72734 .

25 Soravia C, Berk T, Madlensky L, et al. Genotype-phenotype correlations in attenuated adenomatous polyposis coli. Am ₹ Hum Genet 1998;62:1290301 .

26 Kinzler K, Nilbert M, Vogelstein B, et al. Identification of a gene located at chromosome 5q21 that is mutated in colorectal cancers. Science 1991;251: 1366-70.

27 Curtis L, Bubb V, Gledhill S, Morris RG, Bird CC, Wyllie A. Loss of heterozygosity of MCC is not associated with mutation of the retained allele in sporadic colorectal cancer. Hum Mol Genet 1994;3:443-6.

\section{NF2 gene deletion in a family with a mild phenotype}

EDITOR-Neurofibromatosis type 2 (NF2) is an autosomal dominant disorder that predisposes to bilateral vestibular schwannomas and other nervous system tumours. Two clinical subtypes have been proposed. The severe type (Wishart) has an onset before 25 years of age, a rapid course, and multiple nervous system tumours. The mild type (Gardner) has a later onset with a more benign course, often restricted to bilateral vestibular schwannomas. ${ }^{1}$

The NF2 tumour suppressor gene is localised on chromosome 22q12 and encodes a protein called merlin or schwannomin, which is related to a family of cytoskeleton associated proteins. ${ }^{2}{ }^{3}$ Since the identification of NF2, various germline mutations have been identified, ${ }^{4-6}$ as well as somatic mutations. ${ }^{7}$ In general, germline mutations associated with a mild phenotype include missense mutations and small in frame deletions or insertions. ${ }^{5}$
In our study, the proband (III.2) is an 18 year old boy with a mild facial palsy. Slight enlargement of both vestibular branches of the eighth cranial nerve was observed after MRI scanning, but no other clinical features have been observed. His mother (II.4) was operated on at the age of 28 for bilateral vestibular schwannomas; she died at the age of 45 from breast cancer but with stable vestibular schwannomas. The grandmother (I.2) of the proband had progressive deafness followed by surgery for a right sided vestibular schwannoma at the age of 48 after which she died owing to postoperative complications. At necropsy a right and left sided vestibular schwannoma were found.

DNA from the proband and the available family members was prepared from peripheral blood according to standard procedures. Microsatellites were amplified from genomic DNA by the polymerase chain reaction (PCR). Eight polymorphic markers in the NF2 gene region were studied in the family: nf2GAI (intron 1), D22S929 (intron 1), nf2CT3I (intron 1), nf2CAII (intron 3), nf2CAIV (intron 8), nf2CAV (intron 10), nf2CAVI (intron 13), and nf2GAII. ${ }^{8}$ 


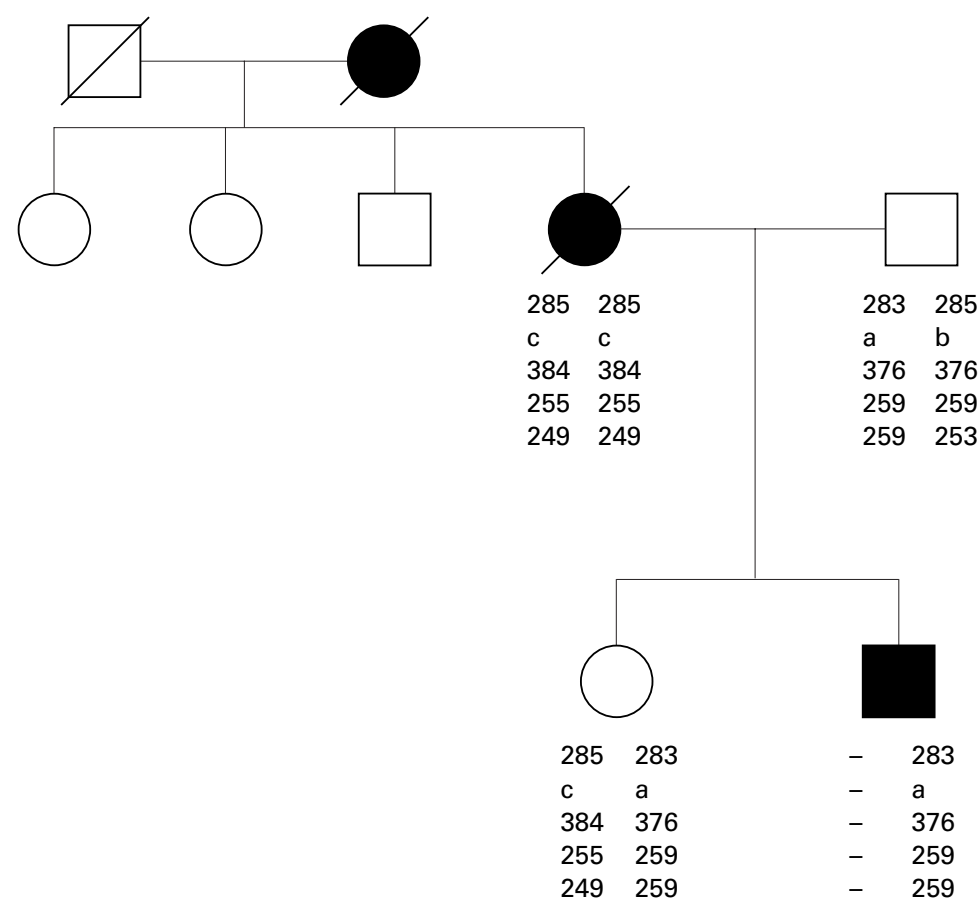

Figure 1 Pedigree of the reported family showing the informative intragenic markers (nf2GAI, D22S929, nf2CT3, nf2CAIV, nf2CAV). The proband shows only paternal alleles.

Cytogenetic studies with $\mathrm{G}$ banding were normal. PCR fragments from the NF2 gene were used as FISH probes, including a pool of exon 1 and intron 1 fragments ( 2 and 0.7 $\mathrm{kb})$, a pool of intron 1 fragments (2-2.5 and $3.5 \mathrm{~kb})$, and a pool of intron 15 fragments $(2-2.8 \text { and } 3.6 \mathrm{~kb})^{9}$ (for primer sequences see http://www.cephb.fr/nf2deletion/). The different PCR fragment pools were used separately and combined as FISH probes. Normal controls were studied in parallel.

In the family we studied, five polymorphic markers were informative. Using these markers we identified the proband (III.2) as a carrier of a deletion in the NF2 region. $\mathrm{He}$ had not inherited any allele from his mother (fig 1). The deleted region extends at least from intron 1 to intron 10 of the NF2 gene, as measured by the microsatellites.

The FISH experiment on peripheral lymphocytes from II.4 confirmed these results (fig 2). The mother of the proband has only one copy of the NF2 gene, suggesting that the deletion extends at least from exon 1 to intron 15. The NF2 gene contains only 17 exons. ${ }^{2}$ This method has

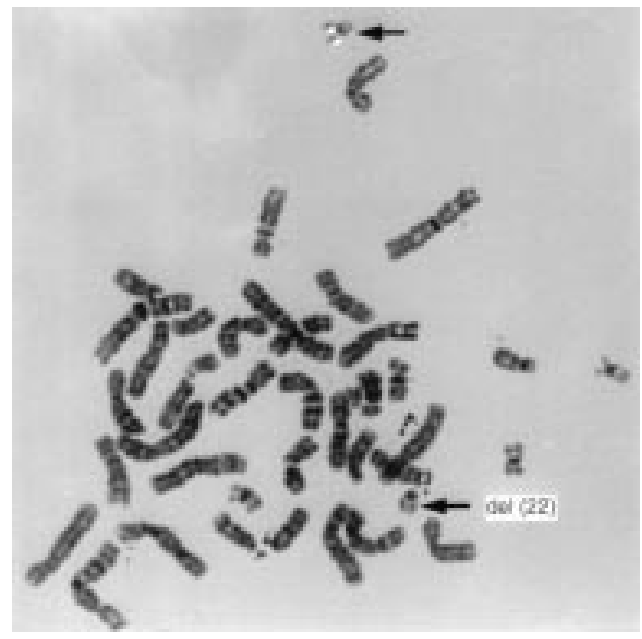

Figure 2 FISH results for the mother of the proband using a pool of NF2 PCR fragments as probe. Arrow shows chromosome 22. been shown to be a very efficient way to detect the large deletion in the NF2 gene.

Affected subjects in this family are heterozygous for a deletion in the NF2 region, which cosegregates with a relatively mild phenotype. Mild phenotypes have recently been reported in NF2 families ${ }^{10}{ }^{11}$ and in five isolated cases with a complete gene deletion. ${ }^{9}$

The NF2 genotype-phenotype correlation is not completely clear yet; however, frameshift and stop mutations which produce a truncated protein are usually associated with severe phenotypes. ${ }^{5}$ On the other hand, large deletions with complete inactivation of the NF2 gene have been observed in patients with a milder phenotype. ${ }^{9}$

In contrast, large NF1 gene deletions are usually associated with a more severe phenotype than point mutations or small deletions or insertions in the NF1 gene. In NF1, however, the deletions are substantially larger than the NF1 gene, indicating the presence of a possible contiguous gene deletion syndrome and thus explaining the more severe phenotype in these patients. ${ }^{12}{ }^{13}$ In the case of NF2 gene deletions, the nature and the exact size of the deletions remains to be determined. Hemizygosity for the NF2 gene seems to have less severe consequences for the phenotype than the presence of a truncated protein. It has been shown that merlin function depends on the formation of an intraand intermolecular complex (homo- and heterodimers). ${ }^{14}$ Truncated proteins may block these molecular interactions and might have an effect on the growth of schwann cells even before the normal NF2 allele has been inactivated.

We would like to thank Renilde Thoelen for expert technical assistance with FISH. CLC is funded by COLCIENCIAS (Colombia). EL is a part time Clinical Researcher of the Fonds voor Wetenschappelijk Onderzoek Vlaanderen (FWO-Vlaanderen).

CATALINA LÓPEZ-CORREA* JESSICA ZUCMAN-ROSSI† HILDE BREMS* GILLES THOMAS† ERIC LEGIUS*

${ }^{\star}$ Centre for Human Genetics, University Hospital Gasthuisberg,

Herestraat 49, 3000 Leuven, Belgium +INSERM U343, Paris, France

Correspondence to: Dr Legius 
1 Evans DG, Huson SM, Donnai D, et al. A genetic study of type 2 neurofibromatosis in the United Kingdom. I. Prevalence, mutation rate, fitness, and confirmation of maternal transmission effect on severity. 7 Med Genet 1992;12:841-6.

2 Rouleau GA, Merel P, Lutchman M, et al. Alteration in a new gene encoding a putative membrane-organizing protein causes neurofibromatosis type 2. Nature 1993;363:515-21

3 Trofatter JA, MacCollin MM, Rutter JL, et al. A novel moesin-, erzin-, radixin-like gene is a candidate for the neurofibromatosis 2 tumor suppressor. Cell 1993;72:791-800.

4 Bourn D, Carter SA, Mason S, Evans DGR, Strachan T. Germline mutations in the neurofibromatosis type 2 tumor suppressor gene. Hum Mol Genet 1994;3:813-16.

5 Ruttledge $\mathrm{MH}$, Andermann AA, Phelan CM, et al. Type of mutations in the neurofibromatosis type 2 gene (NF2) frequently determines severity of disease. Am ₹ Hum Genet 1996;59:331-42.

6 Kluwe L, Bayer S, Baser ME, et al. Identification of NF2 germ-line mutations and comparison with neurofibromatosis 2 phenotypes. Hum Genet 1996;98:534-8.

7 Bianchi AB, Hara T, Ramesh V, et al. Mutations in trancript isoforms of the neurofibromatosis 2 gene in multiple human tumor types. Nat Genet 1994; 6:185-92
8 Legoix P, Legrand MF, Ollagnon E, Lenoir G, Thomas G, Zucman-Rossi J. Characterisation of 16 polymorphic markers in the NF2 gene: application

9 Zucman-Rossi J, Legoix P, Der Sarkissian H, et al. NF2 gene in neurofibromatosis type 2 patients. Hum Mol Genet 1998;7:2095-101.

10 Watson CJ, Gaunt L, Evans G, Patel K, Harris R, Strachan T. A disease-associated germline deletion maps the type 2 neurofibromatosis (NF2) gene between the Ewing sarcoma region and the leukaemia inhibitory factor locus. Hum Mol Genet 1993;2:701-4.

11 Sanson M, Marineau C, Desmaze C, et al. Germline deletion in a neurofibromatosis type 2 kindred inactivates the NF2 gene and a candidate meningioma locus. Hum Mol Genet 1993;2:1215-20.

12 Kayes LM, Burke W, Riccardi VM, et al. Deletions spanning the neurofibromatosis I gene: identification and phenotype of five patients. $\mathrm{Am}$ f Hum Genet 1994;54:424-36.

13 Upadhyaya M, Ruggieri M, Maynard J, et al. Gross deletions of the neurofibromatosis type 1 (NF1) gene are predominantly of maternal origin and commonly associated with learning disability, dysmorphic features and commonly associated with learning disability,
developmental delay. Hum Genet 1998;102:591-7.

14 Gutmann DH, Geist RT, Xu HM, Kim JS, Saporito-Irwin S. Defects in neurofibromatosis 2 protein function can arise at multiple levels. Hum Mol Genet 1998;7:335-45.

\section{Absence of fragile $\mathrm{X}$ syndrome in Nova Scotia}

EDITOR-Fragile $\mathrm{X}$ syndrome is the leading cause of inherited mental retardation, with an incidence that is generally estimated to be about $1 / 1250$ to $1 / 4000$ in males and $1 / 2000$ to $1 / 8000$ in females. ${ }^{1-3}$ An extremely high estimate was reported by Rousseau et $a l,{ }^{4}$ who indicated that as many as 1/259 females from Quebec, Canada, are premutation carriers. In contrast, Tranebjaerg et $a \bar{P}$ reported a prevalence of 0.04/1000 males in Funen, Denmark. The syndrome is characterised clinically by the triad of (1) long, narrow face with protruding chin and large ears, (2) macro-orchidism, and (3) mental retardation. ${ }^{6}$ The molecular basis for the dis- ease is usually an expanded triplet (CGG) repeat located in the $5^{\prime}$ region of the fragile $\mathrm{X}$ mental retardation (FMR1) gene. ${ }^{78}$ In normal subjects, there are fewer than 60 copies of this CGG repeat; carrier females and transmitting males have a premutation that usually ranges from $60-200$ repeats and in affected subjects the number is expanded to $>200$ copies. ${ }^{7}$ The mutations are associated with absence or reduction in FMR1 gene expression. "Fully expanded" alleles are heavily methylated, in contrast to normal alleles, which are unmethylated. ${ }^{9}$

Contrary to what might be expected of a very common disorder that confers a selective disadvantage, normal alleles appear to have a low mutation rate. The conversion of a normal allele to a premutation, or to a full mutation, has not been reported. ${ }^{10}$ Indirect evidence of a low mutation rate is provided by the finding of founder chromosomes. ${ }^{11}$
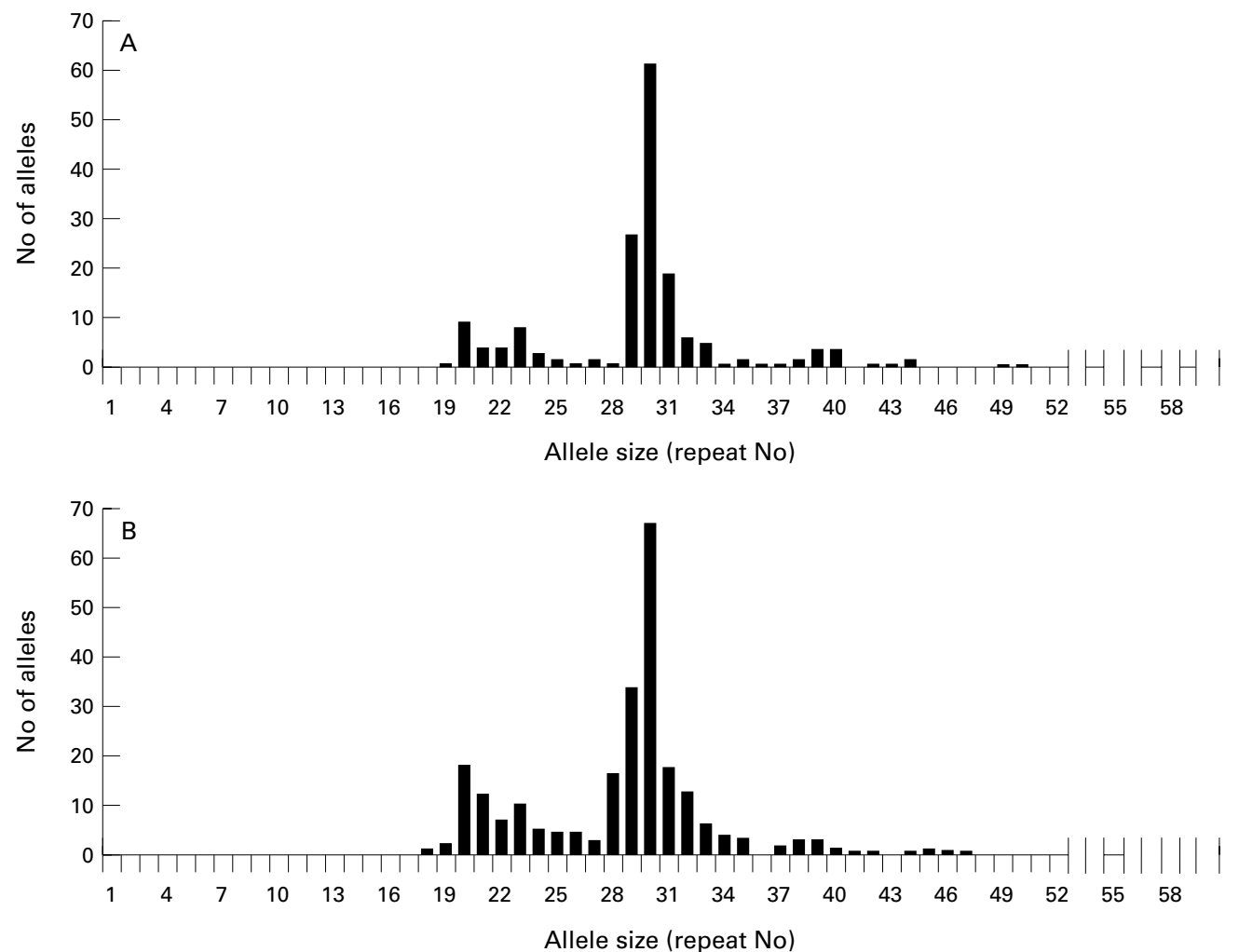

Figure 1 FMR-1 (CGG)n allele size distribution in (A) 167 institutionalised subjects with mental retardation and (B) 1226 random alleles from Guthrie spots. 
Studies of populations from the United States, ${ }^{12}$ France and Spain, ${ }^{13}$ Belgium/The Netherlands, ${ }^{14}$ northern Europe and the United States, ${ }^{15}$ Italy $^{16}$, United Kingdom, ${ }^{17}$ Sweden, ${ }^{18}$ and Finland $^{19-21}$ have shown that FMR1 mutations are in apparent linkage disequilibrium with specific alleles at microsatellite loci FRAXAC1 and DXS548, which are located $7 \mathrm{~kb}$ and $150 \mathrm{~kb}$ proximal to the CGG repeat region, respectively. About two thirds of full mutation FMR1 alleles are associated with a few specific haplotypes. In some reports, the $204 \mathrm{bp}$ allele at the DXS548 locus was associated with approximately $25 \%$ of fragile $\mathrm{X}$ and $8 \%$ of normal chromosomes. The Swedish and Finnish studies found linkage disequilibrium between FMR1 and other DXS548 alleles.

Given the high prevalence of fragile X syndrome reported elsewhere, ${ }^{1-3}$ a population the size of Nova Scotia (one million) is expected to include approximately 200 to 550 cases, with two to six newly identified patients each year. However, despite testing of patients presenting with mental handicap by cytogenetic analysis since $1980(n=423)$ and mutation analysis since $1991(n>650)$, only a single case has been identified. This family had recently moved here from elsewhere in Canada. This disorder may be extremely rare in Nova Scotia; however, patients might be overlooked, misdiagnosed, or not referred for laboratory testing. It has been estimated that more than $50 \%$ of fragile $\mathrm{X}$ cases are undiagnosed in The Netherlands. ${ }^{22}$ Because the implications to extended family members who may be at high risk for having affected children are significant, we screened subjects with mental retardation and no known diagnosis from seven regions of the province of Nova Scotia for CGG expansion. We also investigated the FMR1 allele size distribution in a random sample of Nova Scotians.

Molecular analyses of DNA samples from 177 males with significant mental handicap, using PCR methods previously described by $\mathrm{Fu}$ et $a l^{7}$ and Miller et $a l^{23}$ identified 30 different FMR1 alleles with repeat sizes ranging from 19 to 59 triplets (fig 1A). Although three subjects had repeat sizes in the upper normal range $(54,57,59)$, no premutations or full mutations were found. The absence of mutation in the samples with these large normal alleles was confirmed by Southern blotting using probe $\mathrm{pE} 5.1$ and restriction enzymes EcoRI and BssHII. ${ }^{8}$
The FMR1 CGG repeat size distribution in 1226 random alleles (470 males and 378 females) from Guthrie newborn screening samples (dried blood spots taken at birth) from the general Nova Scotia population was determined according to the methods of Carduci et $a l^{4}$ and $\mathrm{Fu}$ et al. ${ }^{7}$ They contained 36 different allele sizes ranging from seven to 55 repeats (fig $1 \mathrm{~B}$ ). No premutations or fully expanded alleles were identified using this PCR based method. Thirty eight females showed only one allele size. Some of these subjects could be premutation or mutation carriers; however, assuming Hardy-Weinberg equilibrium and allele frequencies observed in male samples, we expected 45 homozygotes, which is more than we observed. The FMR1 allele size distribution differed between the patient and general population sample $\left(\chi^{2}=12.34,42 \mathrm{df}, \mathrm{p}=0.015\right)$. However, this result is apparently because of differences in regional representation in the two samples; chi-square analysis that takes geographical origin of the subjects into account showed no significance differences (analysis not shown).

Table 1 shows the allele distribution at locus DXS548 (determined as described by Zhong et $a l^{12}$ ) within our institutionalised population compared to that in published groups of fragile $\mathrm{X}$ patients and normal subjects. ${ }^{12-212526}$ Because 37 of the 177 samples collected from the institutionalised subjects were either no longer available or did not amplify by PCR at this locus, the sample size for this analysis is 140 . Our institutionalised population is markedly different from each of the published fragile $\mathrm{X}$ groups and more closely resembles the normal groups of other populations. The frequency of the $204 \mathrm{bp}$ allele, which is associated with fragile $\mathrm{X}$ in linkage disequilibrium in many other regions, is low in our population relative to most of the published normal populations, but not as low as one of the Chinese populations reported by Zhong et al. ${ }^{25}$

A comparison of the DXS548 allele distribution between the previously reported fragile $\mathrm{X}$ populations ${ }^{12}{ }^{21}$ showed that these differed from one another $(p=<0.00001)$ to a greater extent than did normal groups $(\mathrm{p}=0.053)$ from the same geographical regions. The greater diversity among fragile $\mathrm{X}$ populations was still apparent, even when the relatively isolated Scandinavian populations ${ }^{18-21}$ were excluded from the calculation $(p=0.00006)$.

Table 1 DXS548 allele size distribution in subjects with mental retardation in Nova Scotia compared to published data from normal and fragile $X$ populations

\begin{tabular}{|c|c|c|c|c|c|c|c|c|c|c|c|c|}
\hline & \multicolumn{9}{|c|}{ Allele size (bp) } & \multirow[b]{2}{*}{ Other } & \multirow[b]{2}{*}{ Total } & \multirow[b]{2}{*}{$p^{*}$} \\
\hline & 190 & 192 & 194 & 196 & 198 & 200 & 202 & 204 & 206 & & & \\
\hline $\begin{array}{l}\text { Nova Scotia } \\
\text { Normal }\end{array}$ & 1 & 3 & 100 & 20 & 0 & 1 & 10 & 5 & 0 & & 140 & \\
\hline USA $^{9}$ & 0 & 6 & 139 & 18 & 2 & 0 & 6 & 15 & 4 & & 190 & 0.076 \\
\hline France $\&$ Spain $^{10}$ & 0 & 3 & 117 & 23 & 0 & 1 & 1 & 15 & 2 & & 162 & 0.031 \\
\hline Beligium \& Holland $^{11}$ & 1 & 0 & 98 & 14 & 0 & 2 & 1 & 14 & 4 & & 134 & 0.006 \\
\hline N Europe \& USA ${ }^{12}$ & 1 & 2 & 60 & 17 & 1 & 0 & 1 & 6 & 3 & & 91 & 0.109 \\
\hline Italy $^{13}$ & 2 & 4 & 162 & 30 & 3 & 0 & 0 & 10 & 4 & & 215 & 0.005 \\
\hline United Kingdom ${ }^{14}$ & 0 & 2 & 138 & 28 & 0 & 0 & 0 & 12 & 8 & & 188 & 0.001 \\
\hline Sweden $^{15}$ & 0 & 0 & 23 & 4 & 0 & 0 & 1 & 0 & & & 28 & 0.76 \\
\hline Finland ${ }^{16}$ & 0 & 0 & 196 & 45 & 0 & 0 & 8 & 28 & 6 & & 283 & 0.002 \\
\hline Finland $^{17}$ & 0 & 0 & 37 & 9 & 0 & 0 & 2 & 4 & 2 & & 54 & 0.23 \\
\hline Finland $^{18}$ & 0 & 0 & 26 & 6 & 0 & 0 & 1 & 3 & 0 & & 36 & 0.72 \\
\hline China $^{23}$ & 0 & 10 & 167 & 25 & 3 & 1 & 0 & 0 & 0 & & 206 & 0.0002 \\
\hline $\begin{array}{l}\text { Sub-Saharan } \text { Africa }^{24} \\
\operatorname{Fra}(X)\end{array}$ & 0 & 1 & 44 & 12 & 4 & 3 & 9 & 1 & 0 & 8 & 82 & 0.004 \\
\hline USA $^{9}$ & 0 & 9 & 49 & 26 & 1 & 6 & 11 & 21 & 2 & & 125 & 0.00001 \\
\hline France $\&$ Spain ${ }^{10}$ & 0 & 0 & 42 & 32 & 0 & 1 & 1 & 29 & 1 & & 106 & 0.00001 \\
\hline Beligium \& Holland ${ }^{11}$ & 0 & 1 & 27 & 14 & 0 & 1 & 0 & 25 & 0 & & 68 & 0.00001 \\
\hline N. Europe \& USA ${ }^{12}$ & 0 & 0 & 22 & 6 & 1 & 2 & 3 & 13 & 3 & & 50 & 0.00001 \\
\hline Italy $^{13}$ & 0 & 7 & 36 & 24 & 0 & 2 & 12 & 36 & 7 & 1 & 120 & $<0.00001$ \\
\hline United Kingdom ${ }^{14}$ & 0 & 4 & 15 & 16 & 0 & 0 & 0 & 8 & 1 & & 44 & $<0.00001$ \\
\hline Sweden ${ }^{15}$ & 0 & 0 & 14 & 12 & 0 & 0 & 0 & 2 & 0 & & 28 & 0.18 \\
\hline Finland $^{16}$ & 0 & 0 & 1 & 54 & 0 & 0 & 0 & 5 & 0 & & 60 & $<0.00001$ \\
\hline Finland $^{17}$ & 0 & 0 & 0 & 35 & 0 & 0 & 0 & 2 & 0 & & 37 & $<0.00001$ \\
\hline Finland $^{18}$ & 0 & 0 & 0 & 24 & 0 & 0 & 0 & 2 & 0 & & 26 & $<0.00001$ \\
\hline
\end{tabular}

${ }^{\star} \mathrm{p}$ values were generated from $\chi^{2}$ tests of independence that were used to compare the DXS548 allele frequency in subjects with mental retardation from Nova Scotia to that of other reported normal and fragile $\mathrm{X}$ populations. 
Studies from elsewhere have shown that approximately $2-10 \%$ of developmentally delayed patients are positive for the fragile $\mathrm{X}$ mutation by cytogenetic or molecular analysis. ${ }^{32-29}$ For example, 16 of 219 male and 13 of 128 female mentally retarded children studied from Birmingham, UK, had mutations in the FMR1 gene. ${ }^{27}$ Similarly, a study of children with special educational needs from Salisbury, UK, found an expanded allele in four out of 180 male and 0 of 74 female cases. ${ }^{28}$ We have analysed a similar number of males with mental handicaps and found none. This patient population and our screen of 1226 random alleles showed bimodal size distributions similar to those reported elsewhere, ${ }^{19} 28$ but identified no allele expansions into the premutation or full mutation ranges. Fragile $\mathrm{X}$ syndrome, as suspected from our previous lack of detection through cytogenetic and molecular testing, is therefore rare in Nova Scotia.

The conclusion that fragile $\mathrm{X}$ syndrome is rare in Nova Scotia is also supported by molecular analysis of the microsatellite locus DXS548 in the same "high risk" patient population with mental retardation. Alleles at this locus have been shown to be in linkage disequilibrium with FMR1 expansions in many populations. ${ }^{11-20}$ We have shown that the allele distribution in our high risk group resembles that of other normal populations, with a dearth of those alleles commonly associated with fragile $\mathrm{X}$.

It is noteworthy that the DXS548 allele distribution in previously studied fragile $\mathrm{X}$ populations ${ }^{12-21}$ is more heterogeneous that those in the corresponding normal populations. ${ }^{30}$ This observation suggests the possibility of multiple origins of the fragile $\mathrm{X}$ mutations from a limited number of pre-premutation alleles, ${ }^{30} 31$ with additional diversity generated by recombination and mutation of tightly linked microsatellite marker loci. Nova Scotia has long been noted for having a high prevalence of specific rare genetic disorders in various regions, for example, Niemann-Pick type D disease, ${ }^{32}$ Huntington disease, ${ }^{33}$ Charcot-Marie-Tooth disease, ${ }^{34}$ acute intermittent porphyria, ${ }^{35}$ Fabry disease, ${ }^{36}$ and nephrogenic diabetes insipidus. ${ }^{37}$ Common ancestry of affected subjects in each of these cases has been documented, and molecular analysis supports the conclusion of a founder effect. Given the low rate of mutation, the absence of fragile $\mathrm{X}$ syndrome in Nova Scotia can be seen as an example of an "absence of founder effect". Considering that our population (approximately one million) has tens of thousands of founders, from multiple founding groups (chiefly English, Scottish, Irish, French, and German immigrants in the 18th and 19 th centuries), this phenomenon appears remarkable.

We would like to thank the institutions, families, and patients who participated in this study, Dr David Nelson for providing the pE5.1 probe, and Karen Cleveland for secretarial support in preparation of this manuscript. We would also like to thank Dalhousie Medical Research Foundation and University Avenue Laboratory Medicine Associates for financial support. PEN is a Medical Research Council of Canada Scholar.

R G BERESFORD* C TATLIDIL $\star$

D C RIDDELL*

J P WELCH†

$M$ D LUDMAN†

P E NEUMANN ${ }^{\star} \ddagger$

W L GREER*

*Division of Molecular Pathology and Molecular Genetics, Department of Pathology, Faculty of Medicine, Dalhousie University, Halifax, Nova Scotia, Canada

tDepartment of Paediatrics, Faculty of Medicine, Dalhousie University, Halifax, Nova Scotia, Canada

$\ddagger$ Department of Anatomy and Neuroscience, Faculty of Medicine, Dalhousie University, Halifax, Nova Scotia, Canada

Correspondence to: Dr Greer, Queen Elizabeth II Health Sciences Centre, VG Site, DNA Laboratory, Haematology, Room 223B, Mackenzie Building, 5788 University Avenue, Halifax, Nova Scotia B3H 1V8, Canada

1 Sherman S. Epidemiology. In: Hagerman RJ, Silverman AC, eds. Fragile $X$ syndrome. Diagnosis, treatment and research. Baltimore: The Johns Hopkins University Press, 1991:69-97.
2 Turner G, Robinson H, Laing S, Purvis-Smith S. Preventive screening for the fragile X syndrome. N Engl f Med 1986;315:607-9.

3 Turner G, Webb T, Wake S, Robinson H. Prevalence of fragile X syndrome. Am F Med Genet 1996;64:196-7.

4 Rousseau F, Rouillard P, Morel ML, Khandjian EW, Morgan K. Prevalence of carriers of premutation-size alleles of the FMR1 gene and implications for the population genetics of the fragile X syndrome. Am f Hum Genet 1995;57:1006-18.

5 Tranebjaerg L, Hilling S, Jessen J, Lind D, Hansen MS. Prevalence of fra (X) in the county of Funen in Denmark is lower than expected. Am f Med Genet 1994;51:423-7

6 Fryns JP. X-linked mental retardation and the fragile X syndrome: a clinical approach. In: Davies KE, ed. The fragile $X$ syndrome. Oxford: Oxford University Press, 1989:1-21.

7 Fu YH, Kuhl DPA, Pizzutti A, et al. Variation of the CGG repeat at the fragile $\mathrm{X}$ site results in genetic instability: resolution of the Sherman paradox. Cell 1991;67:1047-58.

8 Verkerk AJMH, Pieretti M, Sutcliffe JS, et al. Identification of a gene (FMR-1) containing a CGG repeat coincident with a fragile $\mathrm{X}$ breakpoint cluster region exhibiting length variation in fragile X syndrome. Cell 1991; 65:905-14.

9 Oberle I, Rousseau F, Heitz D, et al. Instability of a 550-base pair DNA segment and abnormal methylation in fragile X syndrome. Science 1991;252: 1097-102.

10 Smits APT, Dreesen JCFM, Post JG, et al. The fragile X syndrome: no evidence for any recent mutations. $\mathcal{F}$ Med Genet 1993;30:94-6.

11 Richards RL, Holman K, Friend K, et al. Evidence of founder chromosomes in fragile X syndrome. Nat Genet 1992;1:257-60.

12 Zhong N, Lingling Y, Dobkin C, Brown TW. Fragile X founder chromosome effects: linkage disequilibrium or microsatellite heterogenetity. $\mathrm{Am} \mathcal{F} \mathrm{Med}$ Genet 1994;51:405-11.

13 Oudet C, Mornet E, Serre JL, et al. Linkage disequilibrium between the fragile $\mathrm{X}$ mutation and two closely linked CA repeats suggests that fragile $\mathrm{X}$ chromosome are derived from a small number of founder chromosomes. Am fH Hum Genet 1993;52:297-304.

14 Buyle S, Reyniers E, Vits L, et al. Founder effect in a Belgian-Dutch fragile X population. Hum Genet 1993;92:269-72.

15 Riggins GJ, Sherman SL, Oostra BA, et al. Characterization of a highly polymorphic dinucleotide repeat $150 \mathrm{~kb}$ proximal to the fragile $\mathrm{X}$ site. Am F Med Genet 1992;43:237-43.

16 Chiurazzi p, Genuardi M, Kozak L, et al. Fragile X founder chromosomes in Italy: few initial events and possible explanation for their heterogeneity. $\mathrm{Am}$ f Med Genet 1996;64:209-15.

17 Macpherson JN, Bullman H, Youings SA, Jacobs PA. Insert size and flanking haplotype in fragile $\mathrm{X}$ and normal populations: possible multiple origins for the fragile X mutation. Hum Mol Genet 1994;3:399-405.

18 Malmgren H, Gustavson KH, Oudet C, Holmgren G, Pettersson U, Dahl N. Strong founder effect for fragile X syndrome in Sweden. Eur $\mathcal{F}$ Hum Genet 1994:21:103-9.

19 Haataja R, Vaisanen ML, Li M, Ryyranen M, Leisti J. The fragile X syndrome in Finland: demonstration of a founder effect by analysis of microsatellite haplotypes. Hum Genet 1994;94:479-83.

20 Oudet C, Mornet E, Serre JL, et al. Linkage disequilibrium between the fragile $\mathrm{X}$ mutation and two closely linked CA repeats suggests that fragile $\mathrm{X}$ chromosomes are derived from a small number of founder chromosomes. Am f Hum Genet 1993;52:297-304.

21 Zhong N, Kajanoja E, Smits B, et al. Fragile X founder effects and new mutations in Finland. Am f Med Genet 1996;64:226-33.

22 de Vries BBA, van den Ouweland AMW, Mohkamsing S, et al. Screening and diagnosis for the fragile $\mathrm{X}$ syndrome among the mentally retarded: an epidemiological and psychological survey. Am f Hum Genet 1997;61:660-7.

23 Miller SA, Dykes DD, Polesky HF. A simple salting out procedure for extracting DNA from nucleated cells. Nucleic Acids Res 1988;16:1215.

24 Carducci C, Ellul L, Antonizzi I, Pontecorvi A. DNA elution and amplification by polymerase chain reaction from dried blood spots. Biotechniques 1992;13:735-7.

25 Zhong N, Liu X, Gou S, Houck GE, Li S, Dobkin C, Brown WT. Distribution of FMR-1 and associated microsatellite alleles in a normal chinese population. Am f Med Genet 1994;51:417-22.

26 Chiurazzi P, Destro-Bisol G, Genuardi M, Oostra BA, Spedini G, Neri G. Extended gene diversity at the FMR 1 locus and neighouring CA repeats in a sub-Saharan population. Am ₹ Med Genet 1996;64:216-19.

27 Webb TP, Bundey S, Thake A, Todd J. The frequency of the fragile X chromosome among school children in Coventry. f Med Genet 1986;23:396-9.

28 Jacobs PA, Bullman H, MacPherson J, et al. Population studies of the fragile X: a molecular approach. F Med Genet 1993;30:454-9.

29 Van den Ouweland AMW, de Vries BBA, Bakker PLG, et al. DNA diagnosis of the fragile X syndrome in a series of 236 mentally retarded subjects and evidence for a reversal of mutation in the FMR-1 gene. Am $\mathrm{f}$ Med Genet 1994;51:482-5.

30 Chiurazzi P, Macpherson J, Sherman S, Neri G. Editorial comment: significance of linkage disequilibrium between the fragile $\mathrm{X}$ locus and its flanking markers. Am f Med Genet 1996;64:204-8.

$31 \mathrm{Kolehmainen} \mathrm{K}$. Population genetics of fragile X: a multiple allele model with variable risk of CGG repeat expansion. Am f Med Genet 1994;51:428-35.

32 Winsor EJT, Welch JP. Genetic and demographic aspects of Nova Scotia Niemann-Pick disease (type D). Am f Hum Genet 1978;30:530-8.

33 Winsor EJT, Welch JP. Huntington's chorea in Nova Scotia. Nova Scotia Med Bull June 1997:108-9.

34 Neumann PE, Benstead TJ, Gupta S, Guernsey DL. Sex influenced phenotype in a large Nova Scotia kindred with autosomal dominant Charcot-Marie tooth disease (CMTIA). Can F Neurol Sci 1996; suppl 1:12.

35 Green-Davis S, Neumann PE, Mann OE, et al. Detection of a $\mathrm{R}_{173} \mathrm{~W}$ mutation in the porphobilinogen deaminase gene in a Nova Scotia "Foreign Protestant" population with acute intermitant porphyria: a founder effect. Clin Biochem 1997;30:607-12.

36 Kirkilionis AJ, Riddell DC, Spence MW, Fenwick RG. Fabry disease in a large Nova Scotia kindred: carrier detection using leucocyte $\alpha$-galactisudase activity and an $N c o$ I polymorphism detected by an a-galactosidase cDNA clone. $7 \mathrm{Med}$ Genet 1991;28:232-40.

37 Bode HH, Crawford JD. Nephrogenic diabetes insipidus in North America: the Hopewell hypothesis. N Engl F Med 1969;280:750-4. 